Review

\title{
Advances, Applications, and Comparison of Thermal (Pasteurization, Sterilization, and Aseptic Packaging) against Non-Thermal (Ultrasounds, UV Radiation, Ozonation, High Hydrostatic Pressure) Technologies in Food Processing
}

\author{
Viola Chiozzi $^{1}$, Sofia Agriopoulou ${ }^{2, *(\mathbb{D})}$ and Theodoros Varzakas ${ }^{2, *(\mathbb{D})}$ \\ 1 Department of Chemistry, Materials and Chemical Engineering "Giulio Natta", Politecnico di Milano, \\ Piazza Leonardo da Vinci, 32, 20133 Milano, Italy; viola.chiozzi@mail.polimi.it \\ 2 Department of Food Science and Technology, University of the Peloponnese, Antikalamos, \\ 24100 Kalamata, Greece \\ * Correspondence: s.agriopoulou@uop.gr (S.A.); t.varzakas@uop.gr (T.V.)
}

check for updates

Citation: Chiozzi, V.; Agriopoulou, S.; Varzakas, T. Advances, Applications, and Comparison of Thermal (Pasteurization, Sterilization, and Aseptic Packaging) against Non-Thermal (Ultrasounds, UV Radiation, Ozonation, High Hydrostatic Pressure) Technologies in Food Processing. Appl. Sci. 2022, 12, 2202. https://doi.org/10.3390/ app12042202

Academic Editor: Alexandros Ch. Stratakos

Received: 31 January 2022 Accepted: 17 February 2022 Published: 20 February 2022

Publisher's Note: MDPI stays neutral with regard to jurisdictional claims in published maps and institutional affiliations.

Copyright: (C) 2022 by the authors. Licensee MDPI, Basel, Switzerland. This article is an open access article distributed under the terms and conditions of the Creative Commons Attribution (CC BY) license (https:// creativecommons.org/licenses/by/ $4.0 /)$.

\begin{abstract}
Nowadays, food treatment technologies are constantly evolving due to an increasing demand for healthier and tastier food with longer shelf lives. In this review, our aim is to highlight the advantages and disadvantages of some of the most exploited industrial techniques for food processing and microorganism deactivation, dividing them into those that exploit high temperatures (pasteurization, sterilization, aseptic packaging) and those that operate thanks to their inherent chemical-physical principles (ultrasound, ultraviolet radiation, ozonation, high hydrostatic pressure). The traditional thermal methods can reduce the number of pathogenic microorganisms to safe levels, but non-thermal technologies can also reduce or remove the adverse effects that occur using high temperatures. In the case of ultrasound, which inactivates pathogens, recent advances in food treatment are reported. Throughout the text, novel discoveries of the last decade are presented, and non-thermal methods have been demonstrated to be more attractive for processing a huge variety of foods. Preserving the quality and nutritional values of the product itself and at the same time reducing bacteria and extending shelf life are the primary targets of conscious producers, and with non-thermal technologies, they are increasingly possible.
\end{abstract}

Keywords: food processing; food quality and safety; food preservation; pathogens reduction; process optimization

\section{Introduction}

The prevention of the growth of pathogenic microorganisms in food has advanced through the development of various preservation systems [1]. One of the most serious challenges facing the food industry today is ensuring the food quality. The absence of spoilage and pathogenic microorganisms in food is usually ensured by both the addition of various preservatives and the addition of antimicrobial agents. There are many cases in which chemical agents and synthetic additives are used with controversial ingredients to guarantee the safety and quality of food. In this context and under the constant pressure of consumers for more natural products and for more free chemical foods with clean labels, the food industry is constantly looking for alternative forms of food processing that meet the demands of consumers [2].

The abundance of nutrients found in many categories of foods are an excellent substrate for the growth of microorganisms, and their inactivation is a critical parameter for food safety. Although the preservation and processing by thermal methods, such as pasteurization, sterilization, and aseptic packaging, have been efficient for microorganism and spoilage enzymes inactivation, at the same time, they present reduced results related 
to nutritional characteristics and sensory appearance [3]. Heat-sensitive nutrients are the ones that are usually affected first. Thus, ingredients such as vitamins, color, flavor, and carbohydrates are significantly degraded with the degree of degradation depending on many parameters [4]. In addition to the negative effects that these technologies have on quality characteristics, there are other negative effects that must be seriously considered in choosing the appropriate treatment method. The heat used in these technologies is produced by fuel consumption or by heaters and then transferred to food. The mechanisms of convention or conduction are the main ways of this transfer. Therefore, this option is not an environmentally friendly option, as it imposes energy consumption. In addition, it is well established that thermal processing requires water treatment, which makes it an expensive technology, and it is also technologically unsuitable [5].

On the other hand, several novel non-thermal processing technologies are an alternative to traditional thermal methods, but they do not use temperature to inactivate microorganisms and enzymes [6]. These techniques are constantly gaining popularity in the fields of treatment, preservation, and decontamination [7], as consumers' demand for safe, minimally processed, and high nutritional value foods has become very strong [8]. In the case of plant-based foods, these technologies cause microstructural changes in both plant tissues and plant-based beverages, enhancing the extraction capacity of carotenoids, phenolic compounds, vitamins and minerals extractability, and/or bioaccessibility, which is essential to exert their positive effects on health [9].

High-pressure processing (HPP), ultrasound (US), ultraviolet light (UV), and ozonation are non-thermal processes, which are used at an industrial and commercial scale. Chemical, biological, and physical properties can be modified through these techniques, with positive effects in many quality characteristics. Processing time and intensity, as well as processing conditions, are some of the most important factors associated with the success of these methods, so they should be optimized for each food category before their widespread application $[10,11]$. Figure 1 summarizes some aspects of thermal and non-thermal technologies.

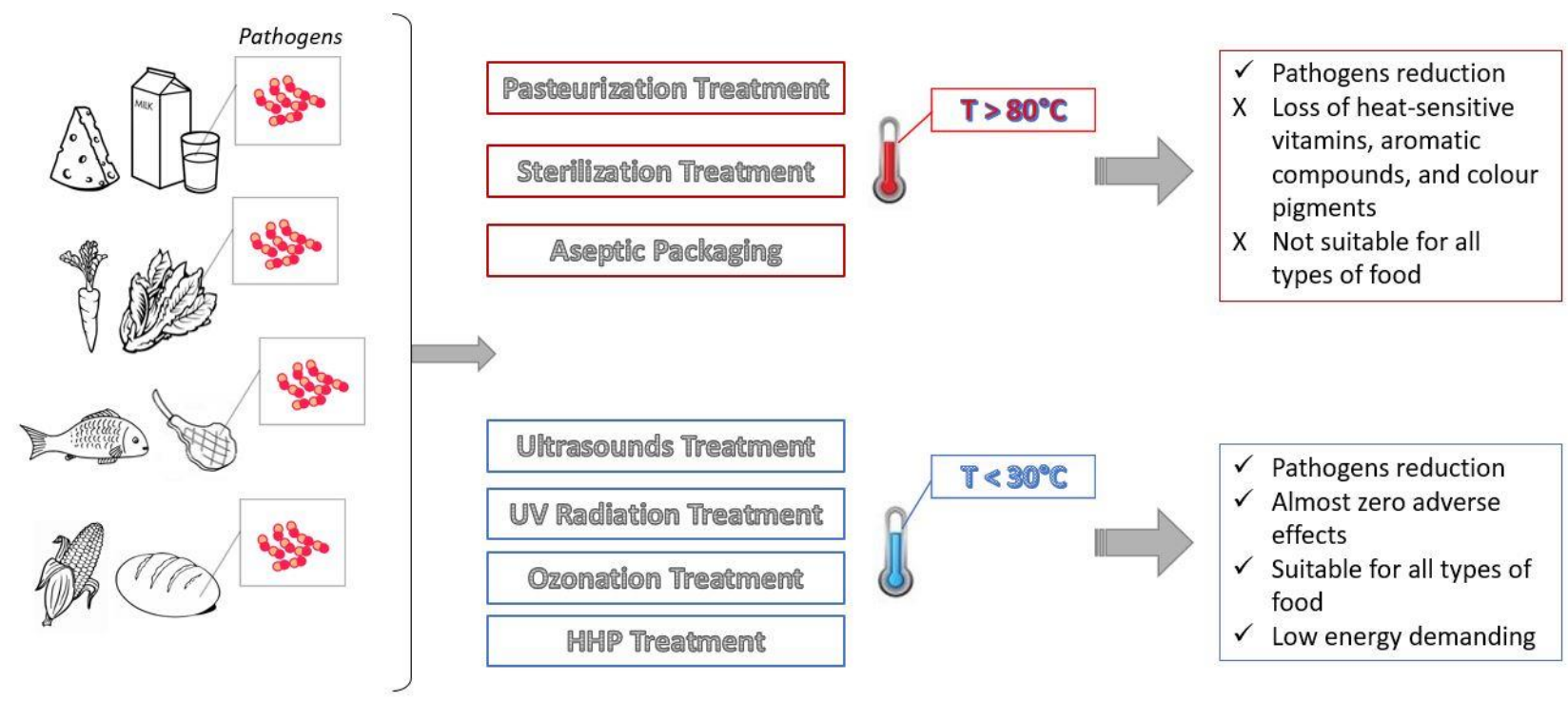

Figure 1. General aspects of thermal and non-thermal techniques.

Furthermore, the development of these new methodology strategies can help the food processing industry in the treatment of raw materials in order to give consumers a high-quality and healthier food, still maintaining cheap prices [12-14].

Due to the existence of many different processing methods, it is important to examine their safety, and it is advisable to evaluate them according to their efficiency and suitability in their application in food production. The purpose of the review is to present the recent 
advances of the last decade (2011-2021) in thermal against non-thermal technologies in food processing and highlight those with the greatest potential in the food industry.

\section{Thermal Technologies in Food Processing}

Pasteurization, Sterilization, and Aseptic Packaging

One of the most important unit operations in food processing is thermal processing.

Food preservation depends on major food operations, such as canning, pasteurization, and sterilization, in order to destroy pathogenic bacteria. Conventional in-container thermal processing involves the hermetical canning of food followed by heat treatment for a specific time-temperature in order to inactive pathogenic bacteria growth and extend the product shelf life with minimum quality deterioration. Examples are high-temperature short time (HTST), low-temperature long time (LTLT) or ultra-high temperature (UHT).

Seal integrity, sufficient process lethality, and post-process hygiene are the most important factors to be considered in thermal processing. A hermetic seal brings seal integrity, thus helping in preventing recontamination and creating an environment inside the container that prevents the growth of other microorganisms of higher heat resistance. It also helps in preventing toxin production from pathogens. The time-temperature schedule for the required process lethality should be effective to eliminate the most heat-resistant mesophilic anaerobic spore-forming pathogen Clostridium botulinum.

Aseptic processing being an alternative thermal food processing and packaging technique involves the packaging of commercially thermally sterilized products into sterilized containers and then sterile sealing under sterile conditions to prevent microbial product recontamination [15]. However, we should stress out that this process cannot stand alone, since it does require one of the thermal processes (pasteurization or sterilization) prior to aseptic packaging. Aseptic systems use ultra-high-temperature (UHT) sterilization, which is a fast heating treatment at temperatures higher than pasteurization temperatures. A typical aseptic process involves receiving a food material, in-flow heating, holding at a sufficient time for sterilization, and cooling down in order to fill it in. Containers are usually pre-sterilized and quality checked. Then, filling and hermetic sealing follows in aseptic containers, as shown in Figure 2 [16,17]. In aseptic filling, the food product and the package are continuously sterilized separately and then meet in the aseptic filler, which has a sterile environment, and this makes it different to other traditional methods of food packaging.

A high rate of microbial destruction and improved product quality, such as better texture, flavor, and color, is achieved with aseptic processing compared to traditional thermal processes, such as canning. The benefits of aseptic processed foods are attractive and include a higher shelf life, better nutritional and sensory properties, and wider packaging sizes and container materials [18].

The design for aseptic processing varies for different foods. There is a demand for aseptic processing of low acid food $(\mathrm{pH}>4.6)$ and high-viscous food containing discrete particles. Aseptic processing design for heterogeneous food products (liquid-particulate food) is more complicated and challenging [19] due to irregular solids' particle size distribution, different residence times, the temperature measurements of moving particles, and the estimation of convective heat transfer coefficients at the particle surface.

The lethality value $\left(\mathrm{F}_{0}\right)$ of an aseptic processing in food is used to quantify target spore inactivation in the sterilization process. Design of the aseptic food processing system should include heat and hold (sterilization) of every particle of food product for at least the minimum time specified in the process [20]. Commercial sterility needs to be accomplished in the coldest location (normally, center) of the fastest moving particle. 


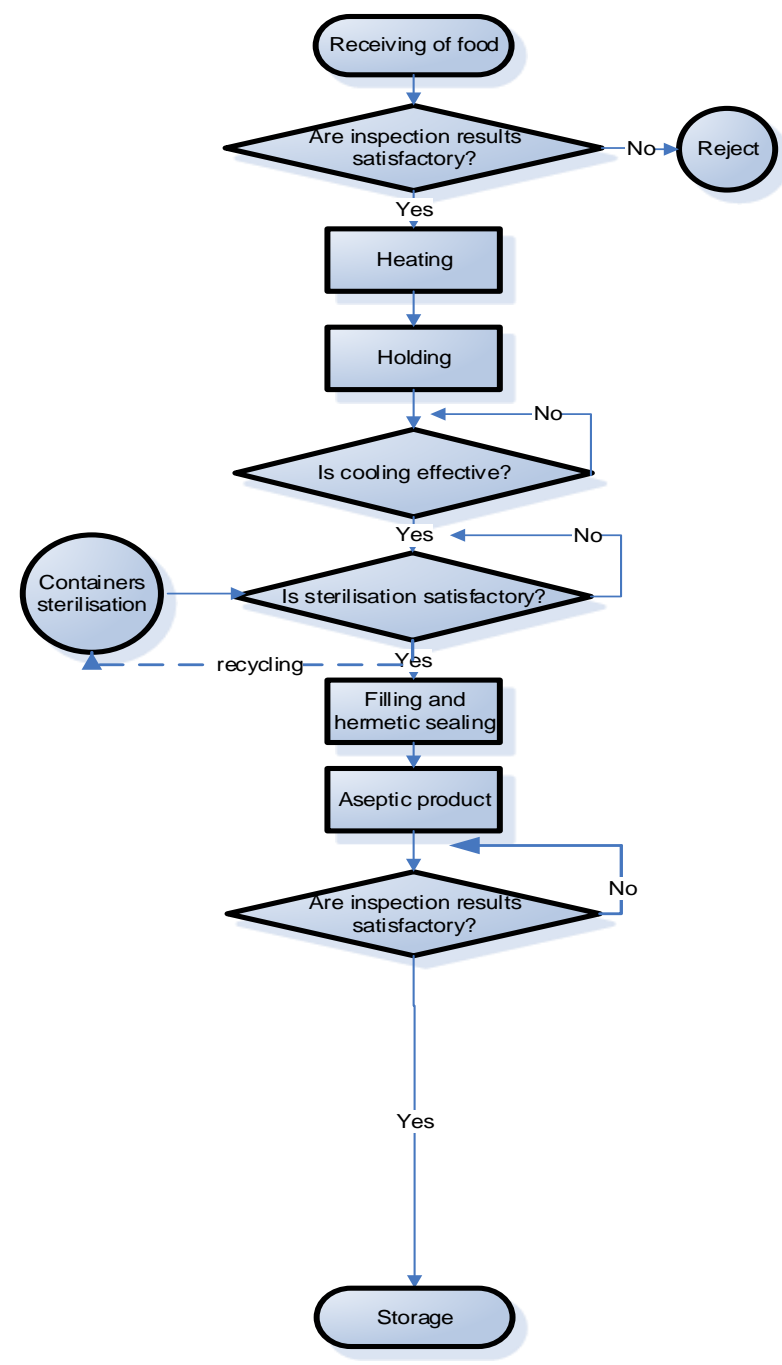

Figure 2. Flow diagram of aseptic processing.

The temperature in the center of the fastest moving particle depends on the properties of the particles and carrier fluid, particles' velocity and rotation, their residence time distribution (RTD), and characterization of the heat transfer mechanism [21,22]. The thermal process should be assessed by determination of the heat transfer coefficient $\left(h_{\mathrm{fp}}\right)$ between the fluid and particle in the continuous flow conditions. The fluid flow field around the solid particle, the thermal and rheological properties of the fluid, and the dimensions of the particle and pipe are key parameters affecting the fluid-to-particle convective heat transfer coefficient $\left(\mathrm{h}_{\mathrm{fp}}\right)$ [17].

The main problem involves the solid particles, especially at the geometrical center position in the product, where sufficient heat treatment or minimum sterilization value should be assured. The particles are hydraulically conveyed through the process equipment in a liquid carrier; hence, it is difficult to measure the temperature in the center of the suspended particles. Therefore, mathematical models should be applied to describe the sterilization process, which are essential for process design and prediction of the particle dynamics and spatial and temporal variations in the temperatures of the particles moving throughout the continuous process system [23].

Ultra-high temperature (UHT) processed and aseptically filled products are described by [24], including products such as liquid dairy products, baby foods, desserts, sauces, soups, fruit juices, and soft drinks. A high heat treatment $\left(135-150{ }^{\circ} \mathrm{C}\right)$ for a very short time (3-5 s) is carried out followed by aseptic filling into a variety of packaging format, including cardboard cartons, plastic bottles, glass bottles, and foil pouches. 
Large plastic materials or metal drums or large flexible pouches could be alternatively employed. Heat (saturated steam, superheated steam, hot air, mixture of hot air and steam), chemicals (hydrogen peroxide, ozone, chlorine, peracetic acid), irradiation (ionizing rays, ultraviolet, infrared), or a combination of these methods are the methods used to sterilize packages for aseptic processing [25].

Pasteurization is a heat treatment method used to kill pathogenic microorganisms in food, helping to reduce or eliminate pathogens in low and high-moisture foods. Technologies employed to pasteurize low-moisture foods include conventional thermal processes such as baking, roasting, and extrusion, controlled condensation steam processes, and energy-based technologies such as irradiation, radio frequency heating, and cold atmospheric plasma [26]. For the microbial inactivation of high-moisture food such as juices or pulp, the methods exploited include thermal pasteurization, dielectric heating, and microwaves, for example [27-29]. Pasteurization is a relatively mild heat treatment of food, usually lower than $100^{\circ} \mathrm{C}$, aimed at destroying the vegetative cells of all pathogenic as well as most nonpathogenic microorganisms. Pasteurization is usually combined with another means of preservation, such as acidity, low water activity, and low-temperature storage [30-33].

Commercial sterilization is the application of heat (or other appropriate treatment) to free food from any viable form of pathogenic and toxin-forming microorganisms, as well as of non-health significant microorganisms, which could grow in the food under normal conditions of the storage and distribution of the product.

According to Stumbo [34] (1973), "Whether the term sterilization or pasteurization is used to label a heat treatment designed to reduce the microbial population of a food, the basic purpose of the heat treatment is the same- that is, to free the food of microorganisms that may endanger the health of food consumers or cause economically important spoilage of the food in storage and distribution."

Steam has been used in the pasteurization of low-moisture foods processes (Table 1) versus irradiation and gaseous pasteurization using ethylene oxide (EtO) or propylene oxide (PPO).

Ethylene oxide $(\mathrm{EtO})$ and propylene oxide $(\mathrm{PPO})$ are fumigants effective in achieving significant reductions of microbial populations on low-moisture foods. EtO is used to treat spices, but it is known to cause loss of volatile compounds [35-37]. PPO is used to treat a variety of low moisture foods including nuts, spices, cocoa beans, and dried fruits [38,39]. Table 1 presents the effect of pasteurization treatments on different microorganisms in human food.

Table 1. Effect of pasteurization treatments on different microorganisms in human food. Adapted from [15].

\begin{tabular}{|c|c|c|c|c|c|}
\hline Process & Food & Experimental Parameters & Target Organism & $\begin{array}{l}\text { Microbial } \\
\text { Inactivation } \\
\text { or Reduction }\end{array}$ & Reference \\
\hline Steam & Paprika & $130-170{ }^{\circ} \mathrm{C}, 4-6 \mathrm{~s}$ & $\begin{array}{l}\text { Indicators } \\
\text { (e.g., Enterobacteriaceae, } \\
\text { coliforms, yeast, mold) }\end{array}$ & $3-4 \log$ reduction & [40] \\
\hline Steam & Pistachios & $88^{\circ} \mathrm{C}, 4 \mathrm{~min}$ & Enterococcus faecium & $4 \log$ reduction & [41] \\
\hline Steam & $\begin{array}{l}\text { Seeds, black } \\
\text { peppercorns }\end{array}$ & $85^{\circ} \mathrm{C}, 1 \mathrm{~min}$ & $\begin{array}{c}\text { Salmonella enterica, } \\
\text { Escherichia coli O157:H7 }\end{array}$ & $>5 \log$ reduction & [42] \\
\hline Steam & Almonds, pistachios & $200^{\circ} \mathrm{C}, 15-30 \mathrm{~s}$ & $\begin{array}{l}\text { S. enterica, E. coli O157:H7, } \\
\text { Listeria monocytogenes }\end{array}$ & $\begin{array}{l}>5 \mathrm{log} \text { reduction in } \\
15 \mathrm{~s} \text { (almonds) and } \\
30 \mathrm{~s} \text { (pistachios) }\end{array}$ & [43] \\
\hline Steam & $\begin{array}{l}\text { Black peppercorn, } \\
\text { cumin seeds }\end{array}$ & $85^{\circ} \mathrm{C}, 1-2 \mathrm{~min}$ & S. enterica & $5 \log$ reduction & [37] \\
\hline Steam & Almonds & $95^{\circ} \mathrm{C}, 25 \mathrm{~s}$ & Salmonella Enteritidis PT 30 & $5 \log$ reduction & [44] \\
\hline
\end{tabular}


The development of several commercially available systems that utilize controlled condensation steam (CCS) processes to pasteurize low-moisture foods has been demonstrated. CSS processes may operate at elevated pressure, at atmospheric pressure, or under vacuum. However, CCS processes maintain temperature near the saturation temperature to control condensation on the product. Pressurized processes (e.g., Ventilex) utilize high temperature $\left(130-170{ }^{\circ} \mathrm{C}\right)$ and short time (4-6 s; HTST), whereas vacuum processes (e.g., Napasol, Steripure, Log5) reduce the saturation vapor pressure and can operate at temperatures below $100{ }^{\circ} \mathrm{C}$ and still maintain saturated steam conditions [29].

In Revtech, Safesteril, and Steristep systems, adding sensible heat to the product along with steam is controlled condensation and maintains the dry saturated condition of steam. Therefore, these CCS processes are named dry steam processes due to the very minimal condensation on the food product.

Another type of dry steam is superheated steam (SHS), where the temperature exceeds that of saturated steam at the same pressure. In order to reach much higher temperatures than the saturation point, SHS is also produced by adding heat to saturated steam using an electric resistance heater [30].

Radio frequency (RF) heating can rapidly raise the temperature of agricultural commodities volumetrically and significantly reduce heating time to avoid the quality loss caused by slower heating rate in conventional thermal treatments [45,46]. RF heating may provide more than 4 log reductions of target pathogens in agricultural commodities [47-49].

It is a potential pasteurization method for controlling Salmonella while maintaining product quality. Li explored the application of RF treatments to control E. coli ATCC 25922 in pre-washed in-shell almonds without quality losses [50].

\section{Non-Thermal Technologies in Food Processing}

\subsection{Ultrasounds}

Ultrasound (US) waves used in food applications can be categorized into low-intensity and high-intensity class. The low-intensity or high-frequency ultrasound waves have a typical frequency greater than $100 \mathrm{kHz}$ and intensities below $1 \mathrm{~W} / \mathrm{cm}^{2}$ and are defined as diagnostic waves due to their ability to evaluate the structure and physicochemical properties of the food product both during processing and storage [51]. The high-intensity and low-frequency ultrasound waves have frequency ranges from 20 to $100 \mathrm{kHz}$, and intensities are in the range of 10 to $1000 \mathrm{~W} / \mathrm{cm}^{2}$.

Differently from low-intensity US, this type of US is considered disruptive, since it produces significant modifications on the physical, biochemical, and mechanical properties of food products [52]. US produces bubbles that undergo collisions. Consequently, these generate cavitation phenomena, resulting in high temperature and pressure up to $5000 \mathrm{~K}$ and $50 \mathrm{MPa}$, respectively [53]. Hence, changes in the $\mathrm{pH}$, stress, temperature, and pressure are caused by these strong explosions and high temperatures. In addition, these changes in an enzyme environment can imply the inactivation of enzymes due to the modifications in the enzyme structure caused by destruction of van der Waals binding and hydrogen bonding, which result in loss of enzyme activity [54,55]. Commonly used devices that produce US are the US probe and US bath, as represented in Figure 3.

Considering all the non-thermal processes, US can be regarded as very versatile. In fact, used alone or in combination with other methods, this technology can ensure high process yields and positive results on the quality of foods. US can significantly assist several industrial processes such as filtration, freezing, separation, drying, emulsion, thawing, brining, oxidation, homogenization, meat tenderization, sterilization, and extraction thanks to their capability of improving energy and mass transfer, mixing, and retention of food characteristics as well as reducing thermal and concentration gradients [56-61]. 
a)

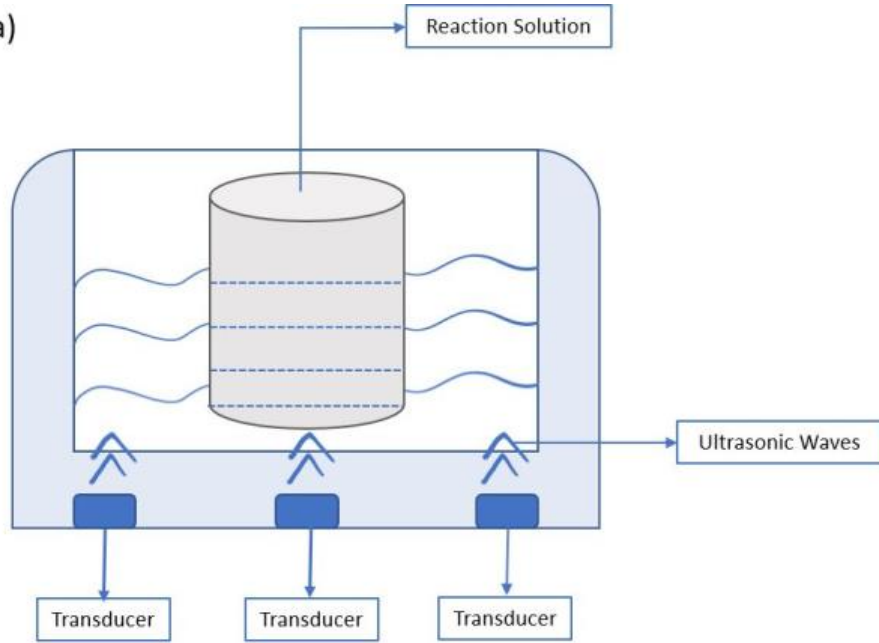

b)

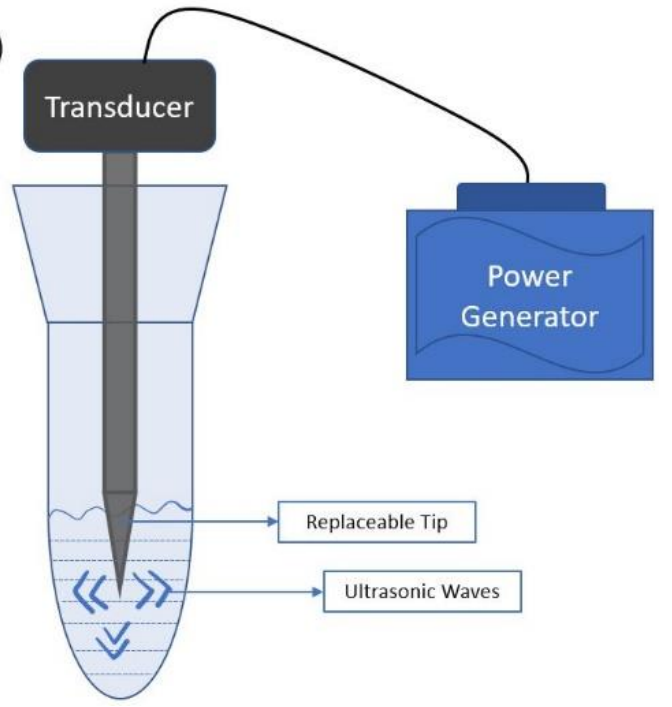

Figure 3. US bath (a) and US probe (b). Adapted from [56].

Additionally, if ultrasounds are applied previous to drying, an enhancement in drying kinetics is always observed, implying a positive effect on the drying process and a reduction in total energy consumption $[4,5]$. Furthermore, if the product it is not soaked in a liquid medium, the loss of hydrophilic nutrients and compounds is reduced [62].

In the freezing-related process, high-intensity US helps to control the size and the size distribution of the ice crystals as well as enhance the efficiency of the freezing and the quality of the frozen food, reducing at the same time the process time [59,63].

This non-thermal technique has been also studied as a method to control the nucleation of a crystallization process, in particular for chocolate, honey, fats, and frozen foods [64]. Moreover, the antioxidant [65], antitumoral [66], anticoagulant [67], and antiinflammatory [68] properties of ultrasound-treated polysaccharides from vegetables, plants, and fungi have been analyzed, as well as nanoparticles production from food polysaccharides $[69,70]$.

In addition to all the good aspects of this emerging food treatment, there are some conditions that cause negative impacts on foods, for example color [71], antioxidants [72], and polysaccharides modifications [73] as well as degradation of fats, radicals formation, and oxidation [74] in high content lipid foods, in particular during emulsification, homogenization, cutting, and extraction steps [75].

From here on, we will present the method of operation and the manifold studies that investigate and utilize US.

The tool most used in the generation of ultrasound is a transducer that transforms electrical signals into acoustic energy of the desired intensity. Magnetostrictive and piezoelectric are the two type of transducers largely used for the production of ultrasound waves. Magnetostrictive transducers behave as electroacoustic transducers to create the ultrasonic waves. The principle of magnetostriction is that these transducers work-which is described as the consequent variation in length per unit length due to magnetization on the application of the magnetic field —only if the material utilized is magnetostrictive. A piezoelectric transducer exploits the conversion among acoustic and electrical energies. The piezoelectric transducer (or sensor) takes advantage of electrical charges generated on its surface when a quartz crystal or any piezoelectric material is subjected to a force designated as piezoelectricity [52].

\subsubsection{Application in Fruits and Vegetables}

Generally for fresh and slightly processed fruits and vegetables, juices, and purees, changes in color, a drop of microbial load, enzyme inactivation, and enhancements in drying characteristics have been noticed [76-78]. US can be used as pre-treatment prior 
to fruits and vegetables drying, since it increases the drying kinetics, in particular if an osmotic solution is employed during the process [4]. This appears with strawberry, papaya, pineapple, pomegranate, guava, and melon. In distilled water, a water loss can occur with apple or papaya. On the other side, banana, mushrooms, strawberry, and melon gain water during US treatment [4]. It has been demonstrated that for strawberries, a $5 \mathrm{~min}$ cleaning step with US can efficiently reduce 16 pesticide residues by $91.2 \%$ [6]. Similarly, for lettuce surfaces, US with frequencies of 20,40 , and $60 \mathrm{kHz}$ can be used to remove $92.31 \%$ of abamectin b1 (AB), $89.36 \%$ of alphamethrin (AL), and $95.25 \%$ of emamectin benzoate $(\mathrm{EB})$ after $8 \mathrm{~min}$ of ultrasonic cleaning without showing any changes in nutritional properties [76].

The ultrasound technology has gained much attention due to its inhibitory effect on browning enzymes thanks to the capability of breaking the cell membranes [5]. In particular, it has been discovered that ultrasound in combination with temperature and high pressure is more effective against polyphenol oxidase (PPO) [53]. In Oriental sweet melon, for $5 \mathrm{~mL}$ of juice, Liu et al. [79] estimated $65 \%$ of inactivation of polyphenol oxidase. As well as with $10 \mathrm{~mL}$ extract of Satsuma mandarin, $63.7 \%$ of PPO was deactivated [80]. Still talking about enzyme inactivation, Yeoh et al. demonstrated that in fresh pineapple, the activity of phenylalanine ammonia lyase increases substantially, whereas the polyphenol oxidase and polyphenol peroxidase (POD) have a drop in relation to the control group [81]. Similarly, pineapple juice had its content of PPO reduced after $10 \mathrm{~min}$ of US treatment as well as a viscosity decline of $75 \%$ [82]. PPO decreased also on fresh cut potatoes after a treatment of $5 \mathrm{~min}$ with US. The degree to which $\mathrm{pH}$ is affected reduced with longer treatments, but no change in color was noticed; a $10 \mathrm{~min}$ treatment has been revealed to damage the potatoes' cell [83].

US has been shown also to assist other techniques, for example extraction. Antioxidant, carotenoids, phenols, anthocyanins, aromas, and natural dyes can be extracted easier from pomegranate, tomatoes, garlic, and grape seeds in combination with US. This happens also with herb and spices and oleaginous seeds from which oil extraction is faster [84].

The sonication of fruit juices involves an enhancement of their quality as well as an increase of shelf life due to a reduction in spoilage microorganisms. In particular, an exposition to US produces in grapefruit juices an enhancement of total antioxidant capacity, ascorbic acid, flavonoids and flavonols, and total phenolics. Furthermore, also apple juice has been studied under US influence, which cause a rise in total carotenoids, viscosity, minerals such as $\mathrm{Na}, \mathrm{K}$, and $\mathrm{Ca}$, and of the concentration of sugar and polyphenolic compounds after a treatment of $60 \mathrm{~min}$ at $20^{\circ} \mathrm{C}$ [85]. Similarly for orange, sweet lime, carrot, and spinach juices, a US sterilization treatment retains most of the nutrients compared to the classic thermal pasteurization [86]. In addition, for Cape gooseberry juice, color values, total phenols, ascorbic acid, carotenoids, and retinol activity equivalent (RAE) have been evaluated after US treatment. Researchers showed a significant decreases in the chromaticity as well as a yellowing in all the juice samples sonicated. Likewise, the other studies registered important increases in total phenols, RAE value, and carotenoids and their availability [87].

US has found application as a pre-treatment for sweet potatoes prior to frying. It helps reduce $71.47 \%$ of the oil uptake during the frying step at $170{ }^{\circ} \mathrm{C}$ [88]. Using US before drying and subsequently frying potato strips is also useful to avoid the oil uptake during the last cooking step [89].

Exploiting US technology, it is also possible to obtain starch nanoparticles (SNP) without any additives from cassava, corn, and yam starches, which contain $8 \%, 25 \%$, and $30 \%$ of amylose, respectively. The SNP production starts with $30 \mathrm{~min}$ of sonication of aqueous starch suspensions at $10 \% \mathrm{w} / \mathrm{w}$. Subsequently, the particles are dried for $48 \mathrm{~h}$ at $35^{\circ} \mathrm{C}$ [90].

\subsubsection{Application in Meat and Fish Products}

The use of ultrasounds in meat from pork, beef, chicken, and rabbits induces tenderness enhancement, improvements in water dynamics of tissue, increase in the water-holding 
capacity and color enhancement, along with acceleration of mass transfer and increase of shelf life [91-94]. Furthermore, US technology assists industrial processes and affects positively some process parameters as observed for meat brining, where the diffusion coefficient (D) increases exponentially with the ultrasonic intensity, and the rate of mass transfer is accelerated. When the lower ultrasound intensity is applied, the value of $\mathrm{D}$ for $\mathrm{NaCl}$ is higher than that of $\mathrm{D}$ for water, whereas the higher ultrasound intensity led to the reverse result [95].

Tenderization and cooling process improvement for poultry meat can be reached by treating the meat with US [96]. US is used to raise meat tenderness, as shown by Kang et al. Thanks to specific operating conditions, the water-holding capacity and tenderness of beef during curing are enhanced. The former is due to the modest oxidation of myosin that starts polymerization, which helps increase water retention; the latter is confirmed by the enhancement myofibrillar fragmentation index values and proteolysis of desmin and troponin-T [97]. More recently, after 7 and 14 days of storage at $4{ }^{\circ} \mathrm{C}$, the tenderization capacity of US has been experimented on beef $m$. Longissimus dorsi muscle samples with $60 \mathrm{~min}$ of sonication. The beef showed a reduction in red color and increased $\mathrm{pH}$, luminosity, fascicle size, and a greater interfibrillary space that results in softer meat [98]. Chang et al. have analyzed the features of intramuscular heat-insoluble collagen as well as the textural properties and meat quality of beef semitendinosus muscle after US treatments of 10, 20, $30,40,50$, and $60 \mathrm{~min}$. The meat color does not change except for a decrease in yellowness, muscle fiber diameter, and filtering residues, which have been reduced by the treatment, but the content of heat-insoluble collagen was not. In general, it has been seen that US treatment deteriorates the stability of collagen and thus meat textural properties [99].

Tenderization through US has been exploited also for squid meat. This causes the muscle fiber to break and proteins degradation, leading to a softer meat [100].

\subsubsection{Application in Cereal Product}

For flour dough and bakery products such as bread, crackers, biscuits, wafers, and batters (pancakes, donuts), researchers have experimented with variations in texture, density, and volume; furthermore, ultrasound treatment has brought enhancements in visual (aspects, color), sensory characteristics, and digestibility [101,102]. Ding et al. have evaluated the physicochemical properties of germinated dehulled rice flour and its energy requirement in germination under US treatment. It has been seen that the treatment transforms the surface microstructure of rice, which facilitated moisture transfer during steam cooking, and it enhances starch hydrolysis and the glucose content [103]. For buckwheat grains, the US impact is considerable, since it modifies the functional properties of the resulting flour. Only $15 \mathrm{~min}$ of US treatment raises the water absorption index and the swelling power of the flour along with the water solubility index and insoluble polyphenols content. In addition, a redness and yellowish enhancement in all processed samples has been observed [104].

Singla et al. investigated the impact of US on the functional properties and structural characteristics of gluten. They have analyzed the textural and cooking peculiarities of noodles prepared with different amounts of US pretreated gluten. The noodles with less pretreated gluten showed similar cooking and textural characteristics to commercial ones. If treated with an increasing number of ultrasonic frequencies, the solubility, water-holding capacity, and oil-holding capacity of gluten rose substantially [105].

\subsubsection{Application in Dairy Products}

In the dairy products industry, the use of ultrasounds can be useful for microbial inactivation, fat reduction, product homogenization, and improvement of the organoleptic properties and nutritional value. Moreover, it is a time-saving process, since it reduces the time required for cheese ripening and fermentation [78,106-108]. This treatment has gained much consideration in the last few years in particular for fermented products, since it helps reduce the processing time and enhance the probiotics viability for products with 
low lactose content. For the latter, US helps to reduce undesirable taste and probiotics or $\beta$-galactosidase additions [106].

The longer the US treatment, the better the stabilization of the emulsion and the droplet size reduction [85,107]. The droplets size has been seen to be reduced both for skimmed milk and goat milk, and an increased homogenization has been observed for cream. During the US process, milk deterioration and lipid oxidation can be avoided by reducing the treatment time and temperature. In yogurt, high-intensity US can be used to make a better homogenization and emulsification by reducing the milk fat globule size, and it can also reduce the fermentation time by improving lactose hydrolysis, enhance gel strength and firmness by increasing the coagulation properties of whey proteins, and stimulate probiotic bacteria. In ice cream manufacturing, during the freezing process, US reduces the ice crystal size, freezing time, and block crust on the freezing surface [108-110].

Still considering dairy products, US ( $>400 \mathrm{kHz})$ can be applied as a method to fractionate liquids, which arrange themselves in layers. For milk, ultrasonic frequencies of $0.4 \mathrm{MHz}$ and $1.6 \mathrm{MHz}$ are used for $5 \mathrm{~min}$ at $35^{\circ} \mathrm{C}$ [85].

\subsubsection{Application in Emulsified Products}

In emulsions such as mayonnaise, mustard, creams, dressings, or oil emulsions, ultrasound is used to increase the stability index, activity index of emulsions, and emulsion capacity $[111,112]$. Table 2 presents different food types, together with the ultrasound process parameters and effects.

\subsection{UV Radiation}

Commonly, ultraviolet (UV) light irradiation has been utilized as a disinfectant for surface, water, and air but has also gained attention in the food industry as a fast and inexpensive method for hygenization of the surfaces of solid foods and liquid foods. Being a non-thermal technology, the advantages of it use are multiple: minimal loss of nutrients and sensorial quality of foods, no toxic residues, and low energy consumption compared with other thermal treatment commonly used for food decontamination. The latter is the main purpose of this technique due to its effectiveness in the inactivation of pathogenic microorganisms and spoilages $[61,113]$.

UV light is the part of the electromagnetic spectrum in the range from 200 to $400 \mathrm{~nm}$, and it can be divided into three regions: from 200 to $280 \mathrm{~nm}$, UV short wave (UV-C); from 280 to $320 \mathrm{~nm}$, UV medium wave (UV-B); and from 320 to $400 \mathrm{~nm}$, UV long wave (UV-A). Light is emitted from a gas discharge at wavelengths characteristic of the elements that compose the gas itself as well as the excitation, ionization, and kinetic energy of them. A gas discharge is a mixture of excited atoms, nonexcited atoms, cations, and electrons generated through a high voltage applied across a volume of gas. A schematization of UV lamp is shown in Figure 4.

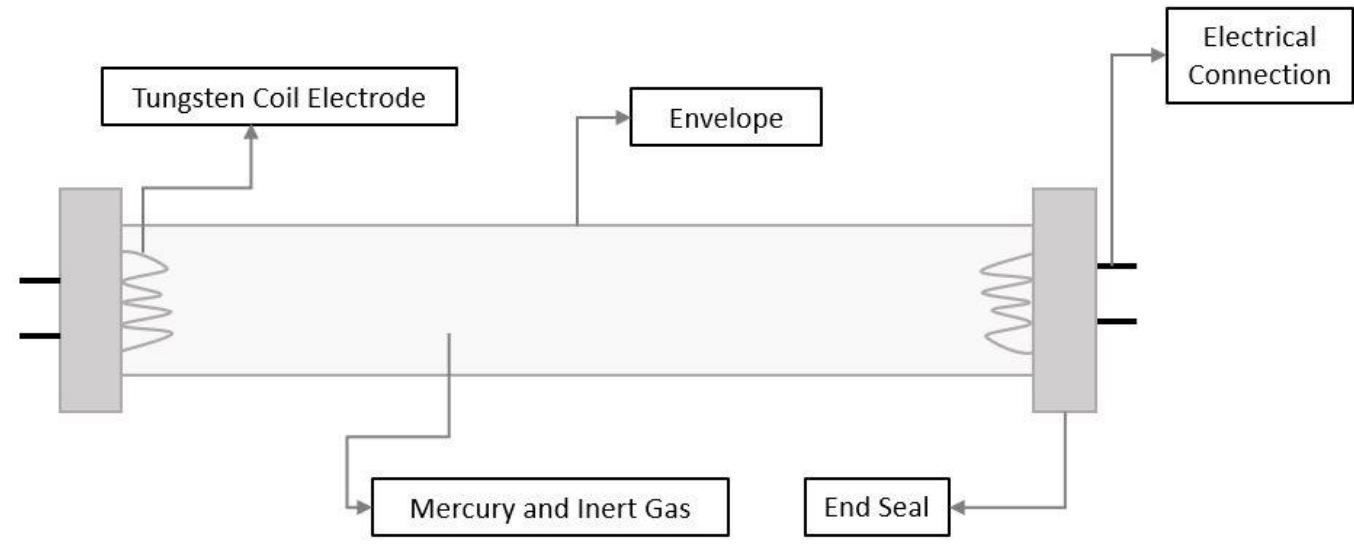

Figure 4. UV lamp. 
Table 2. Different food types together with ultrasound process parameters and effects.

\begin{tabular}{|c|c|c|c|c|c|}
\hline Category & Type & $\begin{array}{c}\text { Process Parameters } \\
\text { (Type/Power/Frequency/Intensity/Time) }\end{array}$ & Use & Effects & Reference \\
\hline \multirow{11}{*}{ Fruits and Vegetables } & Melon & $\begin{array}{c}\text { Water bath } / 25 \mathrm{kHz} / 4870 \mathrm{~W} / \mathrm{m}^{2} / 10,20 \text {, } \\
\text { and } 30 \mathrm{~min}\end{array}$ & Pre-drying treatment & $\begin{array}{l}\text { Samples immersed in distilled } \\
\text { water present negative water loss } \\
\text { values, in sucrose solution, values } \\
\text { are positive and are higher when } \\
\text { the sonication time increased. }\end{array}$ & [4] \\
\hline & Papaya & $\begin{array}{l}\text { Water bath } / 25 \mathrm{kHz} / 4870 \mathrm{~W} / \mathrm{m}^{2} / 10,20 \text {, } \\
\text { and } 30 \mathrm{~min}\end{array}$ & Pre-drying treatment & $\begin{array}{l}\text { Water loss increased with } \\
\text { sonication time. }\end{array}$ & {$[4]$} \\
\hline & Pineapple & $\begin{array}{l}\text { Water bath } / 25 \mathrm{kHz} / 55.5 \mathrm{~W} / \mathrm{L} / 20 \\
\text { and } 40 \mathrm{~min}\end{array}$ & Pre-drying treatment & $\begin{array}{l}\text { The moisture content increased } \\
\text { with increasing sonication time. }\end{array}$ & [4] \\
\hline & Mushrooms & Water bath $/ 25 \mathrm{kHz} / 154 \mathrm{~W} / 20$ and $25 \mathrm{~min}$ & Pre-drying treatment & $\begin{array}{l}\text { Water gain increased with } \\
\text { increasing sonication time. }\end{array}$ & [4] \\
\hline & Strawberry & Water bath $/ 480 \mathrm{~W} / 40 \mathrm{kHz} / 5 \mathrm{~min}$ & Pesticides removal & $\begin{array}{l}\text { Reduction of } 91.2 \% \text { of } \\
16 \text { pesticide residues. }\end{array}$ & [6] \\
\hline & Lettuce & Water bath $/ 300 \mathrm{~W} / 20,40,60 \mathrm{kHz} / 8 \mathrm{~min}$ & Pesticides removal & $\begin{array}{l}\text { Removal of } 92.31 \% \text { of abamectin } \\
\text { b1, } 89.36 \% \text { of alphamethrin and } \\
95.25 \% \text { of emamectin benzoate. No } \\
\text { changes in nutritional properties. }\end{array}$ & [76] \\
\hline & Oriental sweet melon juice & $\begin{array}{l}\text { Ice-water bath } / 100-500 \mathrm{~W} / 20 \mathrm{kHz} / \\
20 \mathrm{~min}\end{array}$ & Inhibitory effect on enzymes & $65 \%$ of inactivation of PPO. & [79] \\
\hline & Satsuma mandarin & Ice-water bath/400 W/20 kHz/30 min & Inhibitory effect on enzymes & $63,7 \%$ of inactivation of PPO. & [80] \\
\hline & Pineapple & $\begin{array}{l}\text { Water bath } / 25-29 \mathrm{~W} / 20,40 \\
37 \mathrm{kHz} / 10-15 \mathrm{~min}\end{array}$ & Inhibitory effect on enzymes & $\begin{array}{l}\text { Decrease in PPO and POD activity. } \\
\text { Enhancement of phenylalanine } \\
\text { ammonia lyase activity. }\end{array}$ & [81] \\
\hline & Pineapple juice & $\begin{array}{c}\text { Titanium probe } / 500 \mathrm{~W} / 19 \mathrm{kHz} / \\
376 \mathrm{~W} / \mathrm{cm}^{2} / 10 \mathrm{~min}\end{array}$ & Inhibitory effect on enzymes & $\begin{array}{l}\text { PPO activity reduced; viscosity } \\
\text { drop of } 75 \% \text {. }\end{array}$ & [82] \\
\hline & Fresh cut potatoes & Water bath $/ 200 \mathrm{~W} / 40 \mathrm{kHz} / 5 \mathrm{~min}$ & Inhibitory effect on enzymes & $\begin{array}{l}\text { PPO activity reduced. } \mathrm{pH} \text { goes } \\
\text { down with longer treatments. No } \\
\text { change in color. After } 10 \text { min, the } \\
\text { potatoes' cells are damaged. }\end{array}$ & [83] \\
\hline
\end{tabular}


Table 2. Cont.

\begin{tabular}{|c|c|c|c|c|c|}
\hline Category & Type & $\begin{array}{c}\text { Process Parameters } \\
\text { (Type/Power/Frequency/Intensity/Time) }\end{array}$ & Use & Effects & Reference \\
\hline & Garlic cloves & Solvent bath $/ 35 \mathrm{kHz} / 30 \mathrm{~min}$ & Aroma extraction & - & [84] \\
\hline & Grape seeds & $\begin{array}{l}\text { 33-67\% ethanol-water bath } / 250 \mathrm{~W} / \\
40 \mathrm{kHz} / 16-34 \mathrm{~min}\end{array}$ & $\begin{array}{l}\text { Phenol, antioxidants, } \\
\text { anthocyanins extraction }\end{array}$ & - & [84] \\
\hline & Grapefruit juice & Probe $/ 28 \mathrm{kHz} / 30,60$ and $90 \mathrm{~min}$ & Microorganism reduction & $\begin{array}{l}\text { Enhancement of total antioxidant } \\
\text { capacity, ascorbic acid, flavonoids, } \\
\text { flavonols, and total phenolics. }\end{array}$ & [85] \\
\hline & $\begin{array}{l}\text { Orange, sweet lime, carrot, } \\
\text { and spinach juices }\end{array}$ & Probe/100 W/20 kHz/15 min & Microorganism reduction & $\begin{array}{l}\text { Sterilization without loss } \\
\text { of nutrients. }\end{array}$ & [86] \\
\hline & Cape gooseberry juice & Water bath $/ 240 \mathrm{~W} / 42 \mathrm{kHz} / 10,20,40 \mathrm{~min}$ & $\begin{array}{c}\text { Post-US } \\
\text { process modifications }\end{array}$ & $\begin{array}{l}\text { Decrease in chromaticity, juice } \\
\text { yellowing, increased total phenols, } \\
\text { RAE value, and carotenoids. }\end{array}$ & [87] \\
\hline & Potatoes strips & Water bath $/ 160 \mathrm{~W} / 28-40 \mathrm{kHz} / 240 \mathrm{~s}$ & Treatment before drying & $\begin{array}{l}\text { Useful to avoid excessive oil } \\
\text { uptake during the frying step. }\end{array}$ & [89] \\
\hline & $\begin{array}{l}\text { Cassava, corn, and yam } \\
\text { starch nanoparticles }\end{array}$ & Probe $/ 20 \mathrm{kHz} / 30 \mathrm{~min}$ & $\begin{array}{c}\text { Starch } \\
\text { nanoparticles production }\end{array}$ & - & [90] \\
\hline \multirow[t]{2}{*}{ Meat and Fish Products } & $\begin{array}{c}\text { Bovine } \\
\text { semitendinosus muscle }\end{array}$ & Water bath $/ 40 \mathrm{kHz} / 11 \mathrm{Wcm}^{-2} / 60-90 \mathrm{~s}$ & $\begin{array}{c}\text { Post-US } \\
\text { process modifications }\end{array}$ & $\begin{array}{l}\text { Improved water-holding capacity, } \\
\text { controlled growth of mesophilic } \\
\text { and psychrophilic bacteria and } \\
\text { total coliforms. Increased meat } \\
\text { luminosity and lowers } \mathrm{pH} \text { without } \\
\text { affecting the redness or yellowness. }\end{array}$ & [91] \\
\hline & Beef & $\begin{array}{c}\text { Probe } / 150 \mathrm{~W} / 20 \mathrm{kHz} / 2,39 \mathrm{Wcm}^{-2} / \\
60-90 \mathrm{~s}\end{array}$ & Meat brining & $\begin{array}{c}\text { Rate of mass transfer is accelerated, } \\
\text { and the value of } \mathrm{D} \text { for } \mathrm{NaCl} \text { is } \\
\text { higher than } \mathrm{D} \text { of water. }\end{array}$ & [95] \\
\hline
\end{tabular}


Table 2. Cont.

\begin{tabular}{|c|c|c|c|c|c|}
\hline Category & Type & $\begin{array}{l}\text { Process Parameters } \\
\text { (Type/Power/Frequency/Intensity/Time) }\end{array}$ & Use & Effects & Reference \\
\hline & Chicken broilers & US bath $/ 25-130 \mathrm{kHz} / 28 \mathrm{~W} / \mathrm{L} / 5$ to $30 \mathrm{~min}$ & $\begin{array}{c}\text { Tenderization } \\
\text { and decontamination }\end{array}$ & $\begin{array}{c}\text { Reduction of about } 40 \% \text { prechiller } \\
\text { process time. }\end{array}$ & [96] \\
\hline & Beef & Probe $/ 300 \mathrm{~W} / 20 \mathrm{kHz} / 20-30 \mathrm{~min}$ & Curing & $\begin{array}{l}\text { Water-holding capacity and } \\
\text { tenderness are enhanced. }\end{array}$ & [97] \\
\hline & $\begin{array}{l}\text { Beef m. Longissimus } \\
\text { dorsi muscle }\end{array}$ & US Bath $/ 40 \mathrm{kHz} / 11 \mathrm{Wcm}^{-2} / 60 \mathrm{~min}$ & Tenderization & $\begin{array}{l}\text { Reduction in red color and } \\
\text { increased } \mathrm{pH} \text {, luminosity, size of } \\
\text { fascicle, and greater } \\
\text { interfibrillar space. }\end{array}$ & [98] \\
\hline & Beef semitendinosus muscle & Water bath/1500 W/40 kHz/10-60 min & $\begin{array}{c}\text { Post-US } \\
\text { process modifications }\end{array}$ & $\begin{array}{l}\text { US treatment deteriorates the } \\
\text { stability of collagen and meat } \\
\text { textural properties. }\end{array}$ & [99] \\
\hline & Squid & Water bath/186.9 W/25.6 kHz/30.8 min & Tenderization & $\begin{array}{c}\text { Broken fiber and proteins } \\
\text { degradation create a softer meat. }\end{array}$ & [100] \\
\hline \multirow{4}{*}{ Cereal Products } & $\begin{array}{c}\text { Quinoa } \\
\text { (Chenopodium quinoa) }\end{array}$ & Water bath $/ 250 \mathrm{~W} / 20 \mathrm{kHz} / \mathrm{Up}$ to $19 \mathrm{~h}$ & $\begin{array}{c}\text { Post-US } \\
\text { process modifications }\end{array}$ & $\begin{array}{l}\text { Increased water solubility and } \\
\text { in vitro starch digestibility, } \\
\text { decreased gelatinization } \\
\text { temperatures, enthalpy changes in } \\
\text { viscosity, gelling capacity, } \\
\text { antioxidant activity, and total } \\
\text { phenolic content. }\end{array}$ & [101] \\
\hline & $\begin{array}{l}\text { Flour batters and similar } \\
\text { thick liquids }\end{array}$ & Probe $/ 2.25 \mathrm{MHz}$ & $\begin{array}{l}\text { Monitoring the } \\
\text { specific gravity }\end{array}$ & - & [102] \\
\hline & Dehulled rice flour & $\begin{array}{c}\text { Water bath } 2000 \mathrm{~W} / 25 \mathrm{kHz} / 16 \mathrm{~W} / \mathrm{L} / \\
5 \mathrm{~min}\end{array}$ & $\begin{array}{c}\text { Post-US } \\
\text { process modifications }\end{array}$ & $\begin{array}{l}\text { Transformed surface } \\
\text { microstructure to facilitate } \\
\text { moisture transfer during } \\
\text { steam-cooking, enhanced starch } \\
\text { hydrolysis, and glucose content. }\end{array}$ & [103] \\
\hline & Buckwheat grains & Water bath/100 W/45 kHz/15 min & $\begin{array}{c}\text { Post-US } \\
\text { process modifications }\end{array}$ & $\begin{array}{l}\text { Rise in the water absorption index, } \\
\text { the swelling power of the flour, } \\
\text { the water solubility index, and } \\
\text { insoluble polyphenols } \\
\text { content. Redness and } \\
\text { yellowish enhancement. }\end{array}$ & [104] \\
\hline
\end{tabular}


Table 2. Cont.

\begin{tabular}{|c|c|c|c|c|c|}
\hline Category & Type & $\begin{array}{c}\text { Process Parameters } \\
\text { (Type/Power/Frequency/Intensity/Time) }\end{array}$ & Use & Effects & Reference \\
\hline & Noodles & $\begin{array}{l}\text { US reaction tank/67 W/L/ } \\
28-40-80 \mathrm{kHz} / 10 \mathrm{~min}\end{array}$ & $\begin{array}{c}\text { Post-US } \\
\text { process modifications }\end{array}$ & $\begin{array}{l}\text { Solubility, water-holding capacity } \\
\text { and oil-holding capacity of gluten } \\
\text { increased. Particle size reduced. } \\
\text { UV absorption and fluorescence } \\
\text { intensity of the } \\
\text { treated gluten increased. } \\
\text { The surface hydrophobicity of } \\
\text { gluten increased. }\end{array}$ & [105] \\
\hline \multirow{6}{*}{ Dairy Products } & Skimmed milk & Probe $/ 28 \mathrm{kHz} / 100 \mathrm{~W} / \mathrm{L} / 30 \mathrm{~min}$ & Fermentation & $\begin{array}{l}\text { Peptide content and viable cells } \\
\text { increased by } 49.5 \% \text { and } \\
43.5 \% \text {, respectively. }\end{array}$ & [107] \\
\hline & Skimmed milk and goat milk & Probe $/ 20-41 \mathrm{~W} / 20 \mathrm{kHz} / \mathrm{Up}$ to $60 \mathrm{~min}$ & $\begin{array}{l}\text { Stabilization and droplet } \\
\text { size reduction }\end{array}$ & $\begin{array}{l}\text { Droplets size reduced both for } \\
\text { skimmed milk and goat milk. } \\
\text { Increased homogenization } \\
\text { for cream. }\end{array}$ & [107] \\
\hline & Yogurt & Probe/150-750 W/20 kHz /10 min & Homogenization & Reduced milk fat globule size. & [108] \\
\hline & Yogurt & Probe $/ 250 \mathrm{~W} / 20 \mathrm{kHz} / 20 \mathrm{~min}$ & Fermentation & $\begin{array}{l}\text { Fermentation time reduced, } \\
\text { enhanced gel strength } \\
\text { and firmness. }\end{array}$ & [110] \\
\hline & Ice cream & Probe $/ 20 \mathrm{kHz} / 0.21 \mathrm{~W} / \mathrm{cm}^{2} / 5 \mathrm{~s}$ & Freezing process support & $\begin{array}{l}\text { Reduced ice crystal size, freezing } \\
\text { time, and block crust on the } \\
\text { freezing surface. }\end{array}$ & [110] \\
\hline & Milk & Probe/0.4-1.6 MHz/5 min & Fractionation & Arrangement in layers. & [86] \\
\hline \multirow{2}{*}{ Emulsified Products } & Mustard & Probe $/ 750 \mathrm{~W} / 20 \mathrm{kHz} / 30 \mathrm{~min}$ & $\begin{array}{l}\text { Post-US process } \\
\text { modifications }\end{array}$ & Increased stability index. & [111] \\
\hline & $\begin{array}{l}\text { Emulsions with low oil } \\
\text { soybean content }\end{array}$ & Probe $/ 120 \mathrm{~W} / 20 \mathrm{kHz} / 1 \mathrm{~min}$ & $\begin{array}{l}\text { Post-US process } \\
\text { modifications }\end{array}$ & $\begin{array}{l}\text { Reduced suspension viscosity and } \\
\text { size of the biopolymer complexes. }\end{array}$ & [112] \\
\hline
\end{tabular}


Microbial inactivation, but also protein damage, is caused by UV light on the DNA genes, in particular by UV-C waves whose maximum germicidal peak is between 260 and $265 \mathrm{~nm}$, the same as the maximum DNA absorption. These types of waves cause the formation of DNA photoproducts, for example pyrimidine 6-4 pyrimidone photoproducts and cyclobutane pyrimidine dimers, which imply DNA mutagenesis and cell death $[113,114]$.

\subsubsection{Application in Fruits and Vegetables}

UV light has been widely explored for the decontamination of fresh fruits and vegetables. In particular, also UV-assisted $\mathrm{TiO}_{2}$ photocatalysis (TUV) [115] has been recently investigated for disinfection from E. coli on oranges' surface and juice [116]. L. monocytogenes, Staphylococcus aureus, E. coli O157:H7, Salmonella typhimurium, and Saccharomyces cerevisiae have been inactivated in commercial apple juice after treatment with TUV followed by a high hydrostatic pressure process [117]. In addition, Quatrini Corrêa et al. have investigated UV-C light irradiation on apple juice in order to lower the population of E. coli, which was reduced after the experiments by $(3.2 \pm 0.4)$ and $(3.8 \pm 0.2) \log _{10}$ colony-forming units CFU/mL [118].

On the other hand, UV light reduces considerably the vitamin C content in apple juice. Orlowska at al. have analyzed the modifications made on juice by continuous monochromatic low-pressure (LPM) and medium-pressure polychromatic (MPM) mercury UV lamps. Vitamin C reduced by $-1.30 \pm 0.07 \%$ with an LPM UV lamp after about $140 \mathrm{~min}$ and by $-5.45 \pm 0.27 \%$ with an MPM UV lamp after almost $5 \mathrm{~min}$. The $\mathrm{pH}$, of value $3.56 \pm 0.01$, was not affected [119].

Low-pressure (LP) UV light combined with mild temperatures on freshly squeezed orange juice inactivate part of E. coli; the treatment reduces of $16.45 \%$ ascorbic acid content and $63.96 \%$ the pectinmethylesterase activity but it does not affect acidity, $\mathrm{pH}$ and color [120]. Furthermore, E. coli and S. typhimurium has been inoculated in coconut milk to evaluate UV-C light effects on these bacteria and the consequences on the milk physicochemical, bioactive, microbial and sensory characteristics. UV-C light does not influence $\mathrm{pH}$, acidity and soluble solids; otherwise phenolic compounds are reduced by $26.6 \%$. Regarding bacteria, these are reduced by $(4.1 \pm 0.1) \log _{10} \mathrm{CFU} / \mathrm{mL}$ after $30 \mathrm{~min}$ of UV-C treatment [121]. Ilse N. Fredericks et al. have investigated the effectiveness of ultraviolet-C radiation (254 $\mathrm{nm}$ ) as a substitute process to the $\mathrm{SO}_{2}$ addition to deactivate microorganisms in grape juices and wine. It has been experimented a $\log _{10} \mathrm{CFU} / \mathrm{mL}$ bacterial drop of 4.97 and 4.89 in Chardonnay and Pinotage, respectively. In Chenin blanc and Shiraz juice, a $\log _{10} \mathrm{CFU} / \mathrm{mL}$ decrease of 4.48 and 4.25 , respectively [122]. Black peppercorns have been analyzed under UV light emitting diode (UV LED) irradiation. After treatments with $280 \mathrm{~nm}$ wavelengths and durations of $20 \mathrm{~min}$, bacillus subtilis concentration decreases to $(6.20 \pm 0.44) \log _{10}$ CFU/g [123]. L. monocytogenes, E. coli, Bacillus subtilis and S. typhimurium, after inoculation in onion powder, garlic powder, cheese and onion powder and chilli powder, have been treated with UVC-LEDs light at wavelengths of $270 \mathrm{~nm}$. A substantial reduction of 0.75 up to $3 \log _{10} \mathrm{CFU} / \mathrm{g}$ has been obtained after $40 \mathrm{~s}$ of UVC-LED exposure times [124].

UV-light has been studied not only as disinfectant method. In their work, Baenas et al. analyze if UVA light and UVC light pre-treatment $\left(1 \mathrm{~kJ} / \mathrm{m}^{2}\right)$ can enhance the concentration of bioactive compounds such as carotenoids, polyphenols and hydrophilic-lipophilic antioxidant capacity in tomatoes during the post-harvest step. Unfortunately, UV irradiation alone does not considerably influences the carotenoid content, neither phenols or polyphenols concentration [125].

\subsubsection{Application in Meat and Fish Products}

Corrêa et al. investigated UV-C light irradiation on beef, pork, and chicken meat in order to lower the population of E. coli. UV-C lamps reduce the number of bacteria by $(1.0 \pm 0.2) \log _{10} \mathrm{CFU} / \mathrm{mL}$ in beef. Regarding chicken and pork, after 4 and 10 min of irra- 
diation, the bacteria decrease by $(1.6 \pm 0.7) \log _{10} \mathrm{CFU} / \mathrm{mL}$ and $(1.6 \pm 0.4) \log _{10} \mathrm{CFU} / \mathrm{mL}$, respectively [118].

Lázaro et al. analyzed which is the most suitable UV-C light intensity to inactivate $S$. typhimurium inoculated in chicken breast meat, stored at $4{ }^{\circ} \mathrm{C}$ for 9 days, without damaging it. The group of meat treated with the highest UV-C intensity showed extended shelf life and lag phase as well as a decrease in the initial bacterial load. Some intensities revealed a more stable yellowness $\left(b^{*}\right)$ value than the other groups; the rise in the biogenic amines, tyramine, cadaverine, and putrescine contents registered for all the analyzed groups should not be considered as an indicator of bacterial growth but as a consequence of the UV treatment [126].

Bacteria and microorganism can also attack fish meat. In this case, UV-light can be an easy method to inactivate these foodborne pathogens. Colejo et al. evaluated the effectiveness of UV-C treatment on vacuum-packaged smoked salmon during refrigerated storage $\left(4 \pm 1{ }^{\circ} \mathrm{C}\right)$ against $L$. monocytogenes, Listeria innocua, S. typhimurium, Salmonella enterica enteritidis, S. aureus, E. coli O157:H7, Aeromonas hydrophila, and Plesiomonas shigelloides. Moreover, after 28 days of storage, the degree of lipid oxidation, color, and external appearance have been evaluated. A precise dosage of UV-C radiation permits inactivation in the range of $(-0.5)$ and $(-1.3) \log _{10} \mathrm{CFU}$ units of the microbial population without important variations in the sensory quality properties of the treated products [127].

\subsubsection{Application in Cereal Product}

UV light irradiation has been tested on cake batters by Konak et al. for different times $(0,1,2$, and $4 \mathrm{~h})$ and subsequently backed applying typical methods or microwaves or a combination of them. The parameters evaluated are chemical composition, water activity, specific volume, crumb and crust color, textural parameters such as hardness, cohesiveness, springiness, and resilience, and sensory characteristics. An increase in UV radiation and time of irradiation leads to an enhancement in browning reactions on the cake. In addition, a rise in specific volume has been observed after 1 or $2 \mathrm{~h}$ of UV treatment. Consumers have noticed an unappealing taste and fragrance as the irradiation time increases; on the other hand, the browning reaction on the cake surface, backed only with conventional methods, has made cakes prepared with UV-light more preferable [128].

UV radiation effects on food products containing gluten are documented by Kumar et al., who focused their research on wheat (Triticum aestivum) flour and its protein modification after UV-C radiation. They observed a decrease in gluten content as well as a rise in total volatile basic nitrogen content and photo-induced thiol-disulfide bridge exchange [129].

\subsubsection{Application in Dairy Products}

Used for milk treatments, UV light reduces considerably the vitamin C content. Orlowska et al. analyzed the modifications made on milk by continuous monochromatic lowpressure (LPM) and medium-pressure polychromatic (MPM) mercury UV lamps. Vitamin $C$ reduced by $-35.13 \pm 1.56 \%$ with an LPM UV lamp after $234 \mathrm{~min}$ and by $-61.67 \pm 3.08 \%$ with an MPM UV lamp after $11 \mathrm{~min}$. The $\mathrm{pH}$, of value 6.68, was not affected [119]. Vitamin $\mathrm{C}$ is not the only one lowered by UV light. A study on cow and goat milk highlights that also vitamins $\mathrm{A}, \mathrm{B} 2$, and $\mathrm{E}$ are damaged by $\mathrm{UV}$ irradiation. The most affected after vitamin $\mathrm{C}$ is vitamin $\mathrm{E}$, then $\mathrm{A}$, and at last vitamin $\mathrm{B} 2$. In cow milk, vitamin $\mathrm{A}, \mathrm{B} 2$, and $\mathrm{E}$ decrease by 8 to $13 \%, 3$ to $10 \%$, and 16 to $33 \%$, respectively, while in goat milk, they were lowered by 1 to $9 \%, 1$ to $2 \%$, and 1 to $48 \%$, respectively [130]. Koca and Öztürk investigated UV light irradiation on the surface of kashar cheese, a kind of pasta-filata cheese, before the packaging step in order to eliminate or control contamination that can happen during the post-processing steps without compromising chemical and sensorial quality. The cheese's surfaces underwent different intensities in a batch UV cabinet system, and the researchers obtained $\log _{10}$ pathogens reductions of $0.34,0.69$, and 2.49 in samples treated with different dosages of radiation. No significant differences in hardness or composition have been found 
in any of the treated cheeses. In addition, during sensory analysis, no color modifications have been perceived. Unfortunately, lipid oxidation, accelerated by light enhancement, has caused a perception of off-flavor [131]. Ricotta is another cheese potentially exploitable by a wide range of microorganisms as a growth medium. It has been artificially inoculated with Pseudomonas fluorescens by Ricciardi et al. and then irradiated with UV-C light. After less than 5 days, the control samples were no more acceptable from the microbiological side, whereas the UV-C irradiated ricotta persisted for more than 6 days without any alteration in sensory properties [132]. Sliced cheese has been inoculated with E. coli, S. typhimurium, and L. monocytogenes and then packaged in order to analyze the effectiveness of UV light irradiation in inactivating these food-borne pathogens living under the plastic packaging. Among the materials used for the packaging (polyethylene terephthalate (PET), polyvinylchloride $(\mathrm{PVC})$, polypropylene (PP), and polyethylene (PE)), the ones that reduced the levels of the pathogens the most are PP and PE films. A thickness of $0.07 \mathrm{~mm}$ allows equal reduction in the three bacteria compared to non-packaged UV-treated samples [133].

In Table 3, it is possible to find the studies where UV is investigated and utilized, which are schematized according to the food type, together with process parameters and effects.

\subsection{Ozonation}

The use of ozone $\left(\mathrm{O}_{3}\right)$ in the food industry has become widespread as it acts primarily as a disinfectant against a variety of microorganisms but also as a means of shelf-life extension of many foods. Meat [134,135], poultry [136], eggs [137], seafood [138], fruits [139,140], vegetables [141-145], juices [146], spices and herbs [147,148], dairy and dairy products [149], and dry foods have been treated with ozone for different purposes, among them sanitization and disinfection purposes [150,151]. Ozone as a non-thermal treatment has great antioxidant activity against bacteria, fungi, viruses, protozoa, and vegetative cells $[152,153]$. Ozone destroys microorganisms by gradually oxidizing vital cellular components, starting first with the sulfhydryl groups and amino acids, contained in proteins and enzymes, and continuing with the oxidation of polyunsaturated fatty acids [154]. Ozone also has significant antioxidant activity against mycotoxins, which are highly toxic substances formed in a variety of agricultural products [155-157], at all stages of their distribution and marketing [158], with the processed products showing little or no chemical residues and pollutants [159]. Ozone has also been shown to modify certain functional properties of foods. Increased shelf life, improved texture, as well as reduced viscosity are some of the effects of ozonation on starch modification in various starch sources such as rice, corn, potato, cassava, and wheat sources [151]. Figure 5 presents the main uses of ozone technology in food processing.

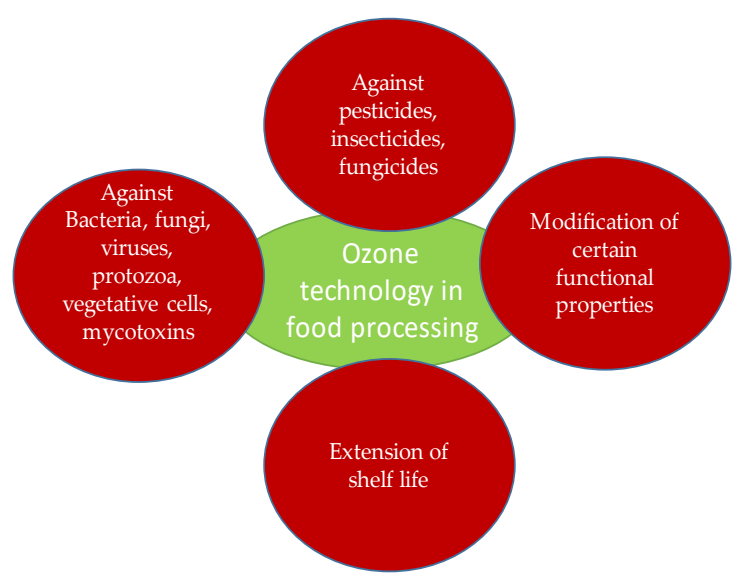

Figure 5. Use of ozone technology in food processing. 
Table 3. Different food types, together with UV light process parameters and effects.

\begin{tabular}{|c|c|c|c|c|c|}
\hline Category & Type & $\begin{array}{c}\text { Process Parameters } \\
\text { (Power/Wavelength/Intensity/Time/Distance } \\
\text { from the Sample) }\end{array}$ & Use & $\begin{array}{l}\text { Effects on Microorganism } \\
\text { and Properties }\end{array}$ & Reference \\
\hline \multirow{8}{*}{ Fruits and Vegetables } & Orange surface & $\begin{array}{c}\text { TUV } 254 \mathrm{~nm} / 35 \mathrm{~W} / 17.2 \mathrm{~mW} / \mathrm{cm}^{2} / \mathrm{up} \\
\text { to } 20 \mathrm{~min}\end{array}$ & Disinfection & E. coli reduced by $4.3 \log _{10} \mathrm{CFU} / \mathrm{mL}$. & [116] \\
\hline & Orange juice & $\begin{array}{c}\text { TUV } 254 \mathrm{~nm} / 35 \mathrm{~W} / 17.2 \mathrm{~mW} / \mathrm{cm}^{2} / \\
20 \mathrm{~min}+\mathrm{HHP} 400 \mathrm{MPa} 1 \mathrm{~min}\end{array}$ & Disinfection & E. coli reduced by $2.4 \log _{10} \mathrm{CFU} / \mathrm{mL}$. & [116] \\
\hline & Apple juice & $\begin{array}{c}\text { TUV } 254 \mathrm{~nm} / 16 \mathrm{~W} / 8.45 \mathrm{~J} / \mathrm{cm}^{2} /+ \\
\text { HHP 400-500-600 MPa }\end{array}$ & Disinfection & $\begin{array}{l}\text { L. monocytogenes, S. aureus totally } \\
\text { inactivated. E. coli and S. typhimurium } \\
\text { reduced by } 7.1 \text { and } 7.2 \log _{10} \mathrm{CFU} / \mathrm{mL} \text {, } \\
\text { respectively. S. cerevisiae reduced by } \\
\quad 6.2 \log _{10} \mathrm{CFU} / \mathrm{mL} \text {. }\end{array}$ & [117] \\
\hline & Apple juice & $\begin{array}{c}\text { UV-C } 254 \mathrm{~nm} / 4 \mathrm{~W} / 13 \mathrm{~mW} / \mathrm{cm}^{2} / \\
5-10 \mathrm{~min} / 1 \mathrm{~cm}\end{array}$ & Disinfection & $\begin{array}{l}\text { E. coli reduced by }(3.2 \pm 0.4) \\
\text { and }(3.8 \pm 0.2) \log _{10} \mathrm{CFU} / \mathrm{mL} \text {. }\end{array}$ & [118] \\
\hline & Apple juice & $\begin{array}{c}\text { LMP UV } 254 \mathrm{~nm} / 20 \mathrm{~W} / \\
10 \mathrm{~mJ} / \mathrm{cm}^{2} / 140 \mathrm{~min} / 30.48 \mathrm{~cm} \\
\mathrm{MPM} \mathrm{UV} 245 \mathrm{~nm} / \\
2660 \mathrm{~W} / 10 \mathrm{~mJ} / \mathrm{cm}^{2} / 5 \mathrm{~min} / 45.72 \mathrm{~cm}\end{array}$ & $V$ irradiation alterations & $\begin{array}{c}\text { Vitamin C reduced by }-1.30 \pm 0.07 \% \\
\text { with LPM lamp after about } 140 \mathrm{~min} \text { and } \\
\text { of }-5.45 \pm 0.27 \% \text { with MPM. pH } \\
\text { not affected. }\end{array}$ & [119] \\
\hline & Orange juice & $\begin{array}{c}\mathrm{LP} \text { UV } 245 \mathrm{~nm} / 8 \mathrm{~W} / 23.72 \mathrm{~J} / \mathrm{mL} / \\
3.6 \mathrm{~min} \text { at } 55^{\circ} \mathrm{C}\end{array}$ & Disinfection & $\begin{array}{c}\text { Reduction of } 16.45 \% \text { ascorbic acid } \\
\text { content and } 63.96 \% \text { pectinmethylesterase } \\
\text { activity. Acidity, pH, and color not } \\
\text { affected; } 6 \log _{10} \text { cycles of inactivation of } \\
\text { E. coli. }\end{array}$ & [120] \\
\hline & Coconut milk & $\begin{array}{c}\mathrm{UV}-\mathrm{C} 254 \mathrm{~nm} / 17 \mathrm{~W} / \\
0.342-1.026 \mathrm{~kJ} / \mathrm{m}^{2} / 30 \mathrm{~min} \text { at } 4{ }^{\circ} \mathrm{C}\end{array}$ & Disinfection & $\begin{array}{l}\text { E. coli and S. typhimurium reduced by } \\
(4.1 \pm 0.1) \log _{10} \text { CFU } / \mathrm{mL} \text {. } \mathrm{pH} \text {, acidity } \\
\text { and soluble solids not affected. Phenolic } \\
\text { compounds reduced by } 26.6 \% \text {. }\end{array}$ & [121] \\
\hline & Grape juice and wine & UV-C $245 \mathrm{~nm} / 30 \mathrm{~W} / 3672 \mathrm{~J} \mathrm{~L}^{-1}$ & Disinfection & $\begin{array}{l}\text { Bacterial drop of } 4.97 \text { and } 4.89 \log 10 \\
\text { CFU/mL in Chardonnay and Pinotage, } \\
\text { respectively. Bacterial drop of } 4.48 \text { and } \\
4.25 \log _{10} \mathrm{CFU} / \mathrm{mL} \text { in Chenin blanc and } \\
\text { Shiraz juice, respectively. }\end{array}$ & [122] \\
\hline
\end{tabular}


Table 3. Cont.

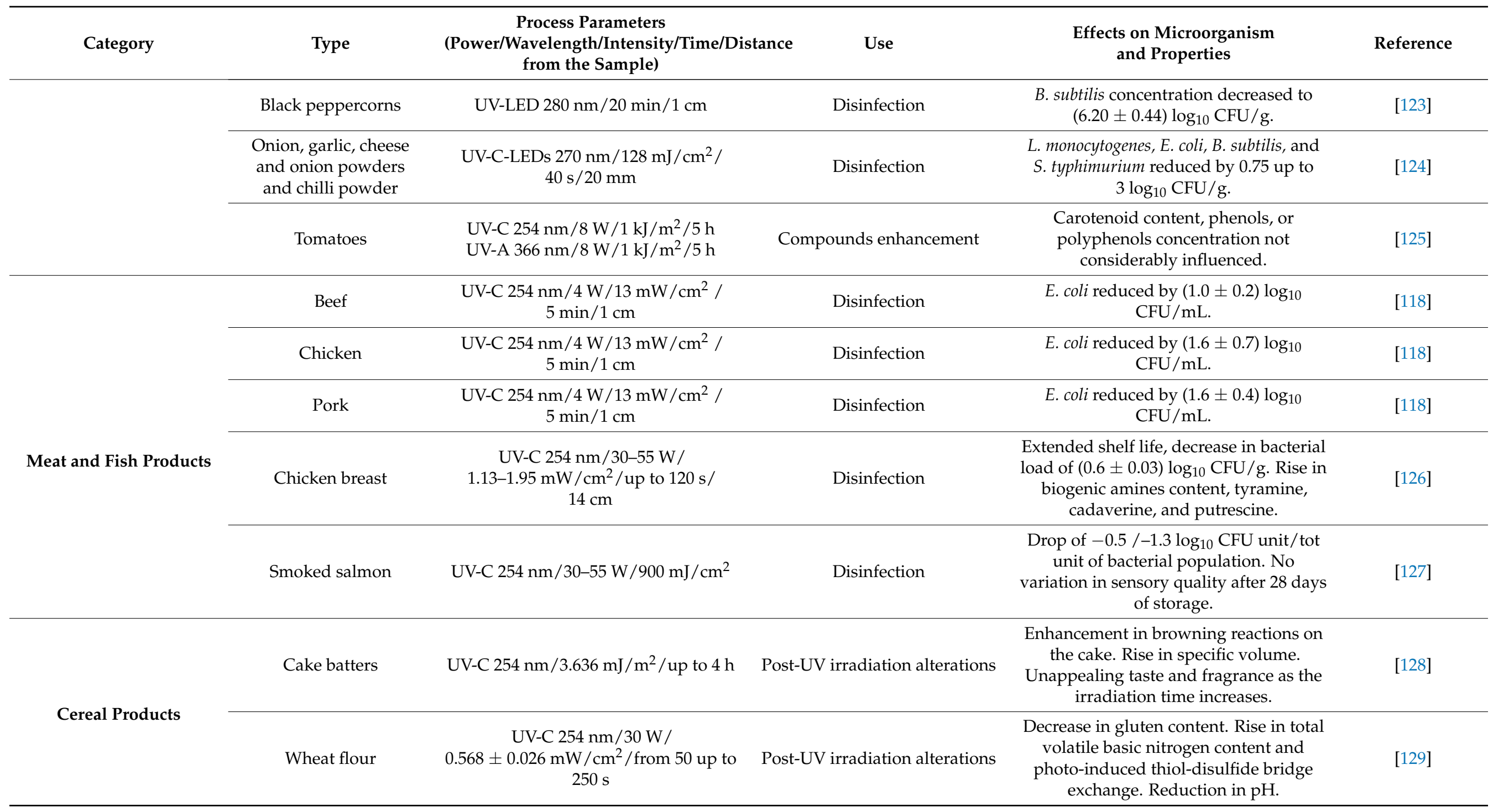


Table 3. Cont.

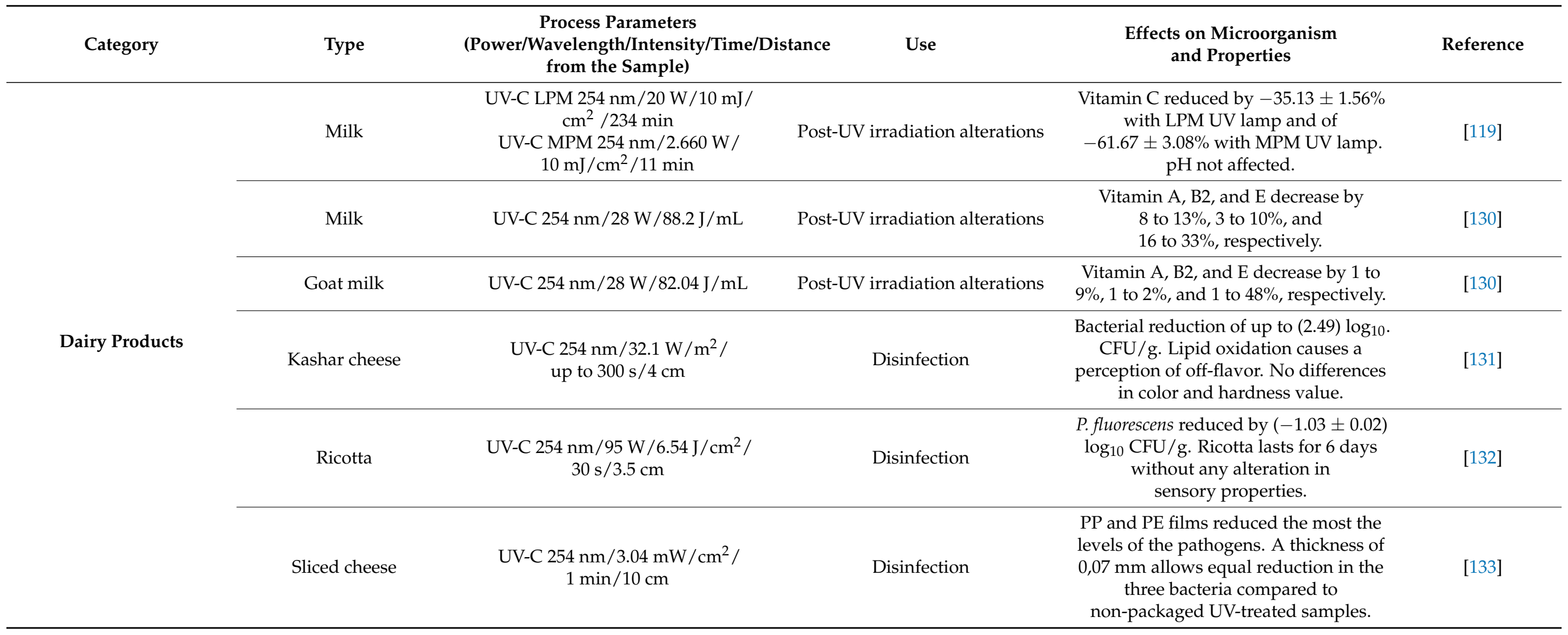


The application of ozone is a bio-friendly technique and commercially feasible technology, making it a promising agent in the food industry. Moreover, there is no need for transportation, and all the treatments with ozone have lower running costs except for the first high cost for installation [160-162]. In addition, there is no need for management facilities of possible waste as there are none, nor are cleaning facilities of the required equipment necessary. However, its use can be dangerous for people who use this technology, as it can show significant toxicological effects at certain concentrations [151].

In 1997, the US-FDA (United States Food and Drug Administration) included ozone in GRAS (Generally Recognized as Safe) additives and officially in 2001 began to be allowed for direct contact with food [162]. Ozone can act as a sterilizing agent in either gaseous or aqueous form [162]. Decomposition caused by the aqueous form of ozone is faster than that caused by its gaseous form [163]. Oxygen cylinders or oxygen concentrators are mainly used for ozone production, but the atmospheric source of oxygen through the ambient air can be also used for the same purpose [162]. Ozone is a triatomic gas that does not require storage in a container, as it can be produced on site [163], and it spontaneously decomposes into oxygen [164]. Ozone production begins with the passage of air or oxygen through a high-energy electric field. Along with ozone, some free radicals are also produced [159], such as hydroxyperoxy $\left(\mathrm{HO}_{2} \cdot\right)$, free hydroxyl $(\mathrm{HO} \cdot)$, and superoxide $\left(\mathrm{O}_{2} \cdot\right)$, which also acts against microorganisms [150]. Table 4 presents recent studies of applications of ozone in different food categories.

\subsubsection{Application of Ozone in Fruits and Vegetables}

The application of ozone to fruits and vegetables focuses mainly on their preservation in combination with their microbiological safety, mycotoxins, and chemical residues. Many researchers have widely studied its use in a variety of fruits and vegetables, and what can basically emerge from their studies is that the effectiveness of using ozone in these food categories is achieved by applying a relatively low concentration of ozone in combination with short exposure time. Regarding their maintenance, it is very well established that ozone is extremely effective in controlling ethylene in storage areas. Although most research highlights the beneficial effects of ozone, there are several research papers that also report adverse effects on quality characteristics that vary from product to product. For example, the degradation of anthocyanin and the color of many fruits has been reported in fruits and juices derived from strawberries and blackberries [161,164], which is caused by the oxidizing power of this triatomic molecule, which reacts and degrades certain organic compounds [159].

For the production of fruits and vegetables, several pesticides are used, such as insecticides and fungicides in order to prevent infestations by insects and fungi. This use carries the risk of the presence of serious residues in fruits and vegetables. The combination of ozone use and ultrasound treatments has been shown to be effective against both pathogens. E. coli, Salmonella, and Listeria, as well as pesticides including thiamethoxam, imidacloprid, and acetamiprid, have been detected in freshly harvested spinach [167]. Application for $5 \mathrm{~min}$ was sufficient to extend the shelf life of minimally treated pepper for 14 days, which was packaged in polypropylene bags and stored at temperature $5 \pm 0.5^{\circ} \mathrm{C}$ and $\mathrm{RH} 85 \% \pm 5 \%$ [168]. 
Table 4. Recent studies of applications of ozone in different food categories.

\begin{tabular}{|c|c|c|c|c|c|}
\hline Food Category & Product & Ozone Form and Concentration & Exposure Time & Effect & Reference \\
\hline \multirow{8}{*}{ Fruits and Vegetables } & \multirow[t]{2}{*}{ Fresh-cut lettuce } & \multirow[t]{2}{*}{ Ozonated water, $2 \mathrm{mg} \mathrm{L}^{-1}$} & $5 \mathrm{~min}$ & $\begin{array}{c}2.57 \text { log reductions against } S \text {. Typhimurium } \\
\text { color properties and sensory quality without } \\
\text { any effect }\end{array}$ & \multirow[t]{2}{*}{ [165] } \\
\hline & & & $15 \mathrm{~min}$ & $\begin{array}{c}\text { 3.47 log reductions against } E \text {. coli color } \\
\text { properties and sensory quality without } \\
\text { any effect }\end{array}$ & \\
\hline & Spinach & Gaseous ozone, 1 ppm & $10 \mathrm{~min}$ & $1 \log$ reduction in E. coli and Listeria spp. & [166] \\
\hline & Fresh-cut green bell peppers & Aqueous ozone, $2.4 \mathrm{mg} \mathrm{L}^{-1}$ & $5 \mathrm{~min}$ & $3.71 \log$ reduction in total plate count & [168] \\
\hline & Strawberry & Aqueous ozone, $0.1 \mathrm{ppm}$ & $2 \mathrm{~min}$ & $\begin{array}{l}\text { Retention the fruit quality and } \\
\text { extension the storage life }\end{array}$ & [169] \\
\hline & Strawberry & Aqueous ozone, $3.5 \mathrm{mg} \mathrm{L}^{-1}$ & $5 \mathrm{~min}$ & Reduced decay caused by B. cinerea almost $17 \%$ & {$[170]$} \\
\hline & Fresh-cut cabbage & Aqueous ozone, $1.4 \mathrm{mg} \mathrm{L}^{-1}$ & $5 \mathrm{~min}$ & $\begin{array}{l}\text { Significantly inhibited aerobic bacteria, } \\
\text { coliforms, and yeasts, } \\
\text { reduced ethylene production }\end{array}$ & [171] \\
\hline & Fresh-cut onions & Aqueous ozone, $1.4 \mathrm{mg} \mathrm{L}^{-1}$ & $5 \mathrm{~min}$ & $\begin{array}{l}\text { Significantly inhibited aerobic bacteria, } \\
\text { coliforms, and yeasts, } \\
\text { reduced respiration rate, reduced residual } \\
\text { levels of five } \\
\text { tested pesticides }\end{array}$ & [172] \\
\hline \multirow{3}{*}{ Fish Products } & White shrimp & Ozonated water, 1 ppm & $10 \mathrm{~min}$ & $\begin{array}{l}\text { Increased shelf life (up to } 24 \text { days), } \\
\text { maintained acceptable sensorial attributes }\end{array}$ & [173] \\
\hline & Sea bream & Aqueous ozone, $640 \mathrm{ppm}$ & $15 \mathrm{~min}$ & $0.29 \log$ reductions in Enterobacteriaceae & [174] \\
\hline & Oyster & $0.6 \mathrm{mg} / \mathrm{L} /$ & $6 \mathrm{~h}$ & $1.3 \log$ reductions in E. coli & [175] \\
\hline Mushrooms & Agaricus bisporus & Gaseous ozone, $2.0 \mathrm{mg} / \mathrm{L}$ & 30 and $60 \mathrm{~min}$ & Increased firmness & [176] \\
\hline
\end{tabular}


Table 4. Cont.

\begin{tabular}{|c|c|c|c|c|c|}
\hline Food Category & Product & Ozone Form and Concentration & Exposure Time & Effect & Reference \\
\hline \multirow[t]{3}{*}{ Meat Products } & Turkey breast meat & Gaseous ozone, $1 \times 10^{-2} \mathrm{~kg} \mathrm{~m}^{-3}$ & up to $8 \mathrm{~h}$ & $\begin{array}{c}2.9 \mathrm{log} \text { reductions in the counts of total aerobic } \\
\text { mesophilic bacteria, } \\
2.3 \mathrm{log} \text { reductions in enterobacteriaceae, } 1.9 \mathrm{log} \\
\text { reductions in yeast-mold, significant changes in } \\
\text { color and pH, } \\
\text { acceptable sensory properties }\end{array}$ & [177] \\
\hline & Beef & Gaseous ozone, $280 \mathrm{mg} \mathrm{m}^{-3}$ & $\begin{array}{l}5 \text { and } 10 \text { min every } \\
30 \mathrm{~min} \text { for } 5 \mathrm{~h}\end{array}$ & $\begin{array}{c}1 \text { log reductions in lactic acid bacteria, } \\
\text { mesophilic and } \\
\text { enterobacteriaceae }\end{array}$ & [178] \\
\hline & Goat meat & Ozonated water, $0.68 \mathrm{mg} / \mathrm{L}$ & $6 \mathrm{~min}$ & $0.50 \log$ reductions in E. coli & [179] \\
\hline \multirow{3}{*}{ Juices and Beverages } & \multirow{2}{*}{ Peach juice } & Gaseous ozone, $0.11 \mathrm{mg} \mathrm{O}_{3} \min ^{1} \mathrm{~mL}$ & \multirow{2}{*}{$12 \mathrm{~min}$} & $\begin{array}{l}\text { 99.5\% decreased POD activities } \\
93.9 \% \text { decreased PPO activities }\end{array}$ & \multirow[b]{2}{*}{ [180] } \\
\hline & & Gaseous ozone, $0.20 \mathrm{mg} \mathrm{O}_{3} \min ^{1} \mathrm{~mL}$ & & $\begin{array}{l}\text { 99.8\% decreased POD activities } \\
97.3 \% \text { decreased PPO activities }\end{array}$ & \\
\hline & Apple juice & Gaseous ozone, $33-40 \mu \mathrm{g} / \mathrm{mL}$ & $8 \mathrm{~min}$ & Increased shelf life in 34 days at $8{ }^{\circ} \mathrm{C}$ storage & [181] \\
\hline Table Olives & Nocellara Etnea & Ozonated water, $6.5 \mathrm{ppm}$ & $10 \mathrm{~min}$ & $\begin{array}{c}1 \log \text { reductions for mesophilic } \\
\text { aerobic bacteria and } \\
1.47 \log \text { reductions for yeasts and mold }\end{array}$ & [182] \\
\hline
\end{tabular}




\subsubsection{Application of Ozone in Juices and Beverages}

Consumers' demands for fresh juices are growing without all these negative effects that thermal pasteurization has on juices. However, ozone leaves no residue when applied to juices, and a concentration limit of $0.4 \mathrm{mgL}^{-1}$ has been set. Factors related to the effectiveness of ozone against pathogenic microorganisms are the $\mathrm{pH}$ of the juice, the concentration, the temperature, and the additives as well as the exposure time and the ozone concentration [164]. The ozonation of juices usually takes place in cylinders with the formation of bubbles [180].

Sánchez et al. reported enzyme peroxidase (POD) and polyphenoloxidase (PPO) activities which were reduced due to treatments with gaseous ozone in peach juice. The researchers exposed peach juice to ozone with different concentrations. Maximum enzyme activities reductions after 12 min of treatment were achieved through the effect of higher ozone concentration [180].

Low concentrations of ozone have been found not to completely inactivate pathogenic microorganisms in juices, whereas high concentrations of ozone degrade some of their quality characteristics such as phenolic content and color. García-Mateos et al. reported that a combination of low ozone concentration $\left(24 \mathrm{mg} \mathrm{L}^{-1}\right)$ with high hydrostatic pressure (179-321 MPa, $5 \mathrm{~min}$ ) was efficient for the stabilization of refrigerated pitaya juice [152].

\subsubsection{Application of Ozone in Meat Products}

The microbial disinfection caused by the use of ozone in meat products is the main goal of this treatment, but sometimes, it also brings some negative effects. The oxidation of myoglobin and oxymyoglobin to methyoglobin is the main reason that ozone treatment in meat leads to discoloration [159]. Particular care should also be taken in the application of high-ozone concentrations, as they can cause the oxidation of lipids and proteins, which are also important quality indicators [183].

Meat is one of the most vulnerable foods and substrates for the growth of a variety of microorganisms including Pseudomonas spp, lactic acid bacteria, Clostridium spp, Aspergillus, and Penicillium. Ozone is used for a wide variety of meats and meat products that are not only fresh but also processed. Among the various types of meat available on the market, chicken meat is of great interest, as it is widely consumed with a significant degree of vulnerability [184]. Muhlisin et al. evaluated the effects of gaseous ozone exposure on the bacterial counts and oxidative properties in chicken breast meat. Coliform and total aerobic and anaerobic bacteria were effectively inhibited by the application of ozone gas at $10 \times 10^{-6} \mathrm{~kg} \mathrm{O}_{3} / \mathrm{m}^{3} / \mathrm{h}$ [185].

Werlang et al. studied the application of $5 \mathrm{ppm}$ gaseous ozone on the microbial and quality attributes of pig carcasses. From the results of the study, two $4 \mathrm{~h}$ treatments with ozone gas proved to be effective not only against total aerobic mesophilic bacteria but also for maintaining its quality [183].

\subsection{High-Pressure Processing}

High-pressure processing (HPP) (also called as high pressure (HP) or high hydrostatic pressure (HHP) or ultra-high pressure (UHP)) is a novel, emerging, and promising non-thermal pasteurization technology, the use of which has steadily increased in food processing since the beginning of the twenty-first century [186-188]. In fact, the application of high-pressure technologies in the food industry is following an exponential growth over the last few years [189]. HPP technology acts as a cold pasteurization process and takes place at pressures ranging between 100 and $1000 \mathrm{MPa}$ and at temperatures from -20 to $60{ }^{\circ} \mathrm{C}$, to solid, liquid, packaged, or unpackaged foods, for several seconds or minutes [190]. A liquid, which is water, is usually used as a means of pressure transfer [8], due to safety and cost considerations [191]. Figure 6 displays a high-pressure processing (HPP) vessel. 


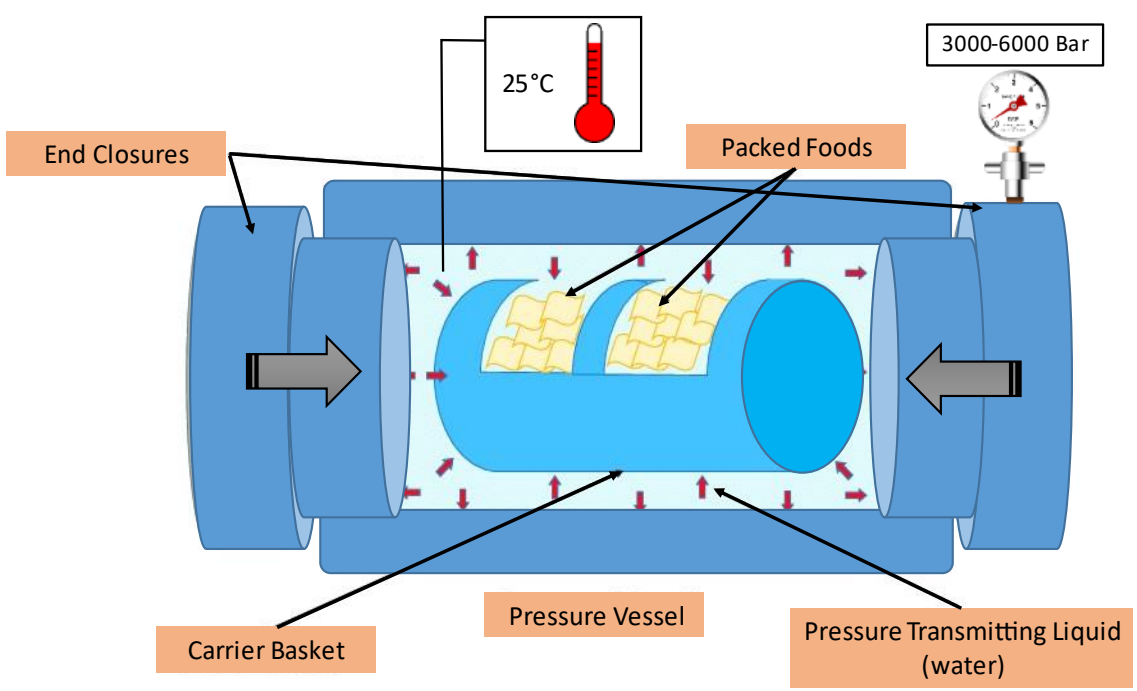

Figure 6. Schematic display of a high-pressure processing (HPP) vessel. Adapted from [192].

The most suitable foods to be processed with the HPP technique are those that have a satisfactory concentration in water and a lack of air gaps. Today, this technique has found wide application, mainly in fruits and vegetables, seafood and shellfish, dairy products, juices and beverages, ready-to-eat meals, and meat products [186]. This technique is unsuitable for the production of low acidity foods, as they require high pressures of 800-1700 MPa in order to inactivate their bacterial spores [193].

Food safety, food quality, and extending the shelf life of high-value refrigerated foods have been the main focus of HPP technology in recent years [194,195]. All these can be achieved, as a variety of pathogenic and spoilage vegetative bacteria, yeasts, molds, viruses, and also spores can be inactivated with HPP treatment [196]. Applying the PP technique has been also shown to enhance healthy attributes in foods. It has been found that the immunoglobulin of dairy products is preserved, the content of resistant starch in cereals is increased, and the glycemic index of fruits is reduced. In addition, this technique promotes the extraction of bioactive compounds from food waste [197].

Key process parameters for this technology include pressure, temperature, and exposure time, but water activity, types of enzymes and/or microorganisms, and the cell growth phase are some extraordinary factors that critically influence the process [198]. The application of pressure can be performed both directly and indirectly [199]. In direct application, a piston moves and causes a change in volume inside the pressure vessel, while in indirect application, the pressure setting in the container varies according to the amount of pressure fluid [186].

The application of this technology disrupts cell walls and membranes, inactivates enzymes, denatures proteins, and causes gel formation [190]. HPP has been officially approved as a food pasteurization alternative to traditional pasteurization by the U.S. Food and Drug Administration (FDA) and the U.S. Department of Agriculture (USDA) [200]. Isostatic pressure above $300 \mathrm{MPa}$ is applied to hermetically sealed containers containing food [190]. In HHP technology, pressure is uniform and simultaneous in all directions of the container, so the pasteurization effect of HPP is not affected by the size, shape, product composition, and nutrient content of the food [201].

\subsubsection{Application of HPP in Fruits and Vegetables}

The extension of shelf life of fresh and minimally processed fruits and vegetables is a key priority at their post-harvest storage [202]. Due to their very high vulnerability, many fruits and vegetables show a relatively short post-harvest life and degraded quality over time [203]. The food industry has turned its attention to the production of minimally processed fruits and vegetables through techniques aimed at maintaining safety and reducing 
their contamination from foodborne pathogens, which are inevitable microorganisms. The HPP technique can help significantly in the processing of minimally processed fruits and vegetables, causing minimal losses in natural aromas and colors and maintaining their high quality [204]. Actually, the effect of HPP treatment on the covalent bonds of low molecular weight compounds of fruits and vegetables is limited, and therefore, the nutrients and sensory properties are well preserved. Since the success of the technique is due not only to the parameters of the treatment but also to factors related to the integrity and texture of the fruit, there may be conflicting results for the same product [205].

The wounding stress caused by the various changes that occur in the membranes of fruits and vegetables is the main effect of the treatment with the HPP technique [206]. The exposure of whole fruits and vegetables to treatment with the HPP technique has caused an increase in their bioactive components [207], such as polyphenols, isothiocyanates, fatty acids, and essential oils [208]. For example, HPP enhanced the extraction of carotenoids, phenolics, and ascorbic acid in whole mangoes [209], free and bound phenolics in whole carrots [206], and total phenolics in strawberries [210]. To date, the accumulation of nutraceuticals caused by the application of the HPP technique has not been fully elucidated, and it is not known whether it is a result of the time of application of the pressure or increases as the pressure increases [206].

The HPP technique has also been used for the extraction of valuable compounds from plant sources, such as anthocyanins from grapes [211], pectin from tomato peel [199,212], carotenoid from tomato peel [213], and pectin from potato waste peel [214].

\subsubsection{Application of HPP in Meat and Fish Products}

Fish and seafood are among the most vulnerable foods, and they pose a major threat to public health, especially when eaten raw or undercooked. Foodborne bacterial pathogens, such as L. monocytogenes and S. enterica, significantly affect the quality, and the HPP technology can contribute to effective microbiological safety [215]. In a very recent study, Boziaris et al. applied the HHP technique in frozen fish fillets and caused a reduction in L. monocytogenes and S. enterica without significant effect on the quality [215].

A total of 500,000 tons of HPP product are traded annually on the planet with readyto-eat meat products occupying the largest share in this market [200]. The HPP technique has caused the inactivation of pathogens such as Campylobacter jejuni [216], E. coli [217], L. monocytogenes [218,219], and S. enterica [220]. Although HPP is effective against spoilage and pathogenic microorganisms in meat, it can cause some unpleasant effects on its quality, related to color, appearance, and texture completely dependent on the intensity of the pressure to be exerted [221-223].

The application of the HPP technology begins with the sealing of meat samples in flexible plastic containers in vacuum conditions. These containers are placed in vessels/chambers, which are filled with the pressure transmitter medium. The pressure transmission is independent of direct or indirect contact with the sample and takes place in a uniform manner [222].

The HPP technique may have a synergistic effect with essential oils in the treatment of foodborne pathogens such a Salmonella and Listeria. Chuang et al. (2020), reported $5.25 \log$ reduction against L. monocytogenes and $6.01 \mathrm{log}$ reduction against S. enterica in fresh ground chicken meat after HPP treatment at $350 \mathrm{MPa}$ for $10 \mathrm{~min}$ and $4^{\circ} \mathrm{C}$ with $0.60 \%$ carvacrol treatment [221].

\subsubsection{Application of HPP in Juices and Beverages}

HPP technology has been used primarily to reduce pathogens and spoilage enzymes in juices $[191,200]$. In addition, through this technique, the shelf life of the juices is extended, while it seems to be effective in maintaining the sensory and nutritional quality [224]. Enzymes such as ascorbic acid oxidase (AAO), polyphenol oxidases (PPO), and peroxidase (POD) are found naturally in fruit and vegetables and modify quality characteristics related to texture, taste, color, and nutritional value [225]. The enzymatic browning of juices is 
a result of high enzymatic activity, which causes the degradation of valuable bioactive compounds [226]. Both pasteurization and inactivation of these enzymes can be performed through the HPP treatment, although studies have shown that in relation to heat treatment, this technique is not as effective in the degradation of enzymes [227,228].

\subsubsection{Application of HPP in Dairy Products}

Dairy products are generally characterized as vulnerable foods with neutral $\mathrm{pH}$ levels and high water activity (>0.9), and their shelf life is short. Through the HPP technique, quality characteristics of milk, such as texture and taste, remain unchanged and at the same time, their shelf life is extended [6]. The several classes of immunoglobulins present in dairy products have positive effects on human health, and the treatment with the HPP technique against the traditional thermal pasteurization can maintain its content [197]. Sousa et al. (2014) found that in human colostrum, immunoglobulin A ( $\operatorname{IgA}$ ), immunoglobulin M (IgM), and immunoglobulin $\mathrm{G}(\mathrm{IgG})$ were not significantly affected when treated at $200 \mathrm{MPa}$ for $2.5,15$, and $30 \mathrm{~min}$ in $8{ }^{\circ} \mathrm{C}$ [229].

\subsubsection{Application of HPP in Emulsified Product}

The HPP technique has been used successfully in the processing of mayonnaise, spreadable dressings, sauces, and other emulsified foods, as it is a technique without the use of chemicals and also without causing a deterioration in their sensory quality. Sethi et al. (2017) evaluated the quality and stability of mayonnaise enriched with green mango after treatment with high pressure. The optimum conditions for high oxidative and emulsion stability of mayonnaise were the application of $435 \mathrm{MPa}$ pressure for $5 \mathrm{~min}$ and the addition of green mango pulp at the rate of $28 \%$ [230]. Recently, Pallarés et al. used HPP technology (600 MPa for $5 \mathrm{~min}$ at room temperature) for the decontamination of different juice models from alternariol and aflatoxin B1, achieving a reduction of $24 \%$ for AFB1 and 37\% for $\mathrm{AOH}$ [231]. Table 5 presents recent studies of applications of high-pressure processing in different food categories. 
Table 5. Recent studies of applications of high-pressure processing in different food categories.

\begin{tabular}{|c|c|c|c|c|c|c|}
\hline Food Category & Product & Pressure & Exposure Time & Temperature & Effect & Reference \\
\hline \multirow{2}{*}{ Fruits and Vegetables } & Dried strawberry & $400 \mathrm{MPa}$ & $10 \mathrm{~min}$ & $5^{\circ} \mathrm{C}$ & $\begin{array}{l}\text { Increased total phenolic content, same content in } \\
\text { vitamin C }\end{array}$ & [232] \\
\hline & Grapes & $200-550 \mathrm{MPa}$ & $10 \mathrm{~min}$ & $<30^{\circ} \mathrm{C}$ & $+80 \%$ extraction of anthocyanins & [211] \\
\hline Fish Products & Frozen pink salmon fillets & $250 \mathrm{MPa}$ & $3 \mathrm{~min}$ & $-22^{\circ} \mathrm{C}$ & $\begin{array}{l}3 \log \text { reduction against L. monocytogenes and } \\
\text { S. enterica }\end{array}$ & [215] \\
\hline \multirow{3}{*}{ Meat Products } & Frozen chicken breast & $500 \mathrm{MPa}$ & $1 \mathrm{~min}$ & $5^{\circ} \mathrm{C}$ & $\begin{array}{l}\text { Salmonella spp inactivation and preserve } \\
\text { color parameters }\end{array}$ & [233] \\
\hline & Chicken fille & $500 \mathrm{MPa}$ & $10 \mathrm{~min}$ & $20^{\circ} \mathrm{C}$ & $\begin{array}{l}\text { S. Enteritidis inactivation and } \\
\text { increased shelf life }\end{array}$ & [220] \\
\hline & $\begin{array}{l}\text { Poultry- and pork-based semidried } \\
\text { fermented sausage }\end{array}$ & $600 \mathrm{MPa}$ & $960 \mathrm{~s}$ & $5^{\circ} \mathrm{C}$ & L. monocytogenes and C. perfringens were below $\mathrm{LOQ}^{3}$ & [234] \\
\hline \multirow{4}{*}{ Juices and Beverages } & Sugarcane based mixed beverage & $300-500 \mathrm{MPa}$ & $10-20 \mathrm{~min}$ & $40-60^{\circ} \mathrm{C}$ & Inactivation in $\mathrm{PPO}^{1}(79 \%)$ and $\mathrm{POD}^{2}(72 \%)$ activity & [235] \\
\hline & Pawpaw pulp & $600 \mathrm{MPa}$ & $76 \mathrm{~s}$ & $4{ }^{\circ} \mathrm{C}$ & Significantly decreased PPO & [236] \\
\hline & Cloudy carrot juice & $300 \mathrm{MPa}$ & \multirow{2}{*}{$5 \mathrm{~min}$} & \multirow{2}{*}{$22^{\circ} \mathrm{C}$} & Inactivation in POD (31\%) & \multirow{2}{*}{ [236] } \\
\hline & & $600 \mathrm{MPa}$ & & & Inactivation in PPO (57\%) & \\
\hline \multirow{2}{*}{ Dairy Products } & Raw milk & $600 \mathrm{MPa}$ & $5 \mathrm{~min}$ & $18^{\circ} \mathrm{C}$ & $\begin{array}{c}5 \log \text { reductions for E. coli, Salmonella and } \\
\text { L. monocytogenes }\end{array}$ & [237] \\
\hline & Cow and goat milk & $450 \mathrm{MPa}$ & $7 \mathrm{~min}$ & $15^{\circ} \mathrm{C}$ & Increased shelf life (up to 22 days to $8^{\circ} \mathrm{C}$ ) & [238] \\
\hline
\end{tabular}

${ }^{1} \mathrm{PPO}$, polyphenol oxidase; ${ }^{2} \mathrm{POD}$, peroxidase; ${ }^{3} \mathrm{LOQ}$, limit of quantification. 


\section{Microfluidization}

As in the previous described non-thermal technologies, microfluidizer is a modern process that produces strong changes in the food matrix as well. The aim of this technology is to transform two immiscible liquids into a very stable emulsion thanks to very high pressures up to $200 \mathrm{MPa}$.

It can be exploited in many field such as cosmetic and pharmaceutical industries but also in the case of food processing and agricultural sectors [239]. The most important advantage is that it can solve problems related with emulsion instability such as sedimentation, creaming, or turbidity in beverages [240]. Microfluidizers are able to modify proteins, starch, and fiber structures as well as deactivate enzymes and potential pathogens [241,242].

Despite these many advantages, its application in industrial processing is rarely reported, and research on microfluidization technology, also in the case of food field, is still at the laboratory stage [243].

\section{Membrane Technology}

Differently from microfluidizers, membrane technology is widely used in the food industry, becoming one of the most exploited non-thermal techniques over the last few decades [244]. Usually, membrane processes are categorized in more specific groups: microfiltration, ultrafiltration, nanofiltration, reverse osmosis, and electrodialysis [245].

These processes utilized membranes usually classified taking into account the average pore sizes and, according to the latter, are capable of retaining species of different molecular weights. The product flows throughout the membrane thanks to an external applied pressure or exploiting a pressure gradient.

This technology finds application for many kinds of fruit juices since permits it the clarification, concentration, and deacidification of the juice itself; clarification and stabilization are guaranteed with this method also for wines and beer.

During sugar processing, purification and demineralization are achieved by membrane operations.

In the dairy industry, membrane technology is extensively used due to its versatility; it is possible to eliminate bacteria and spores from milk, separate casein micelles, fractionate fats from whole milk, and concentrate and demineralize milk [244].

\section{Discussion}

Traditional food preservation methods can reduce the number of pathogenic microorganisms to safe levels. However, these methods lead to the loss of organoleptic characteristics such as heat-sensitive vitamins, aromatic compounds, and color pigments. Recently, non-thermal technologies have attracted increased attention [203]. High hydrostatic pressure, cold plasma, UV light, pulsed electric field, and ultrasound (US) can effectively destroy microorganisms with almost zero adverse effects on the nutritional value and sensory properties of food materials. These methods apply mild temperature conditions and shorter processing times, which retain the flavor, enhance the shelf life, and inactivate enzymes $[18,19,22]$. This makes them attractive for producing high-quality and fresh products.

Ultrasound offers many advantages such as a decrease in the use of fossil fuels to provide energy during food processing, including drying and heating; decreases in the amount of water consumed; enhancement of productivity, and retaining the nutrients of the product $[18,46]$. Ultrasound waves (frequency $>20 \mathrm{kHz}$ ) with specific intensity and amplitude are used for inactivation of microorganisms in foods. The cavitation phenomenon is responsible for microbial destruction [46], since cavitation bubbles are formed through cycles of pressure created by high-intensity ultrasound. The bubbles grow over several compression/rarefaction cycles, reaching an unstable size, and then they collapse, leading to the release of energy. Very high shear forces are induced, creating high-temperature and pressure conditions ( $5000 \mathrm{~K}$ and $5000 \mathrm{~atm}$ ) and leading to the structural destruction of many microorganisms $[33,48]$. Furthermore, their benefits go beyond the inactivation of 
microorganisms: enhancement of compounds [85], meat tenderization [98], mass transfer acceleration [95], improved emulsification and homogenization [109], and so on.

$\mathrm{UV}$, as a physical preservation technology, is surely a fast and handy way to reduce or eliminate pathogens; in particular, it has been revealed as a promising alternative to traditional thermal treatment for liquid foods, post-processing treatment for cheese and meat, and shelf-life extension of fresh products [114], while still maintaining low energy demands. On the other side, UV radiation is less effective with turbid liquids with particulates, due to strong light absorption, scattering, or reflection effects. In addition, it is necessary to be careful about some compounds that can be damaged by the radiation $[119,128,129]$, generating a reaction that can ruin the flavor and the food itself [88]. Similarly, also, ultrasounds occasionally can provoke color [71], antioxidants [72] and polysaccharides modifications [73], degradation of fats, radicals formation and oxidation [74] in high content lipid foods, due to the strong effects of cavitation phenomena.

Ozone is a potent oxidant and disinfecting agent that does not require thermal energy, so this technology should be considered suitable for heat-sensitive foods [160]. The bactericidal effect of ozone has been proved on a wide variety of organisms, including Gram-positive and Gram-negative bacteria, vegetative cells, and spores. The exposure to fruits and vegetables with ozone increases the shelf life of the products, and it leaves no residues, since it decomposes quickly [246]. However, this treatment is not advised for meat decontamination since it oxidized myoglobin and oxymyoglobin to methyoglobin, leading to meat discoloration [159].

High hydrostatic pressure processing has potential in the development of health foods and at the same time can enhance or retain the nutritional value of raw material and food products. The color, taste, quality, and nutritional content of food are not affected by HPP technology and remain at their original prices [247]. Moreover, HPP can be exploited as a method in combination with existing technologies to reduce extraction time while extracting functional components and developing and improving low-sodium food products while still maintaining microbial safety [156]. High-pressure processing has a high cost: an average of 1 million euros. The machinery for HPP equipment can range in price anywhere from $\$ 500,000$ to more than $\$ 3$ million dollars per machine [248]. Bhargava et al. (2021) demonstrate that ultrasounds have low cost [52]. The cost for UV is also low, according to Koutchma (2009) [249].

\section{Conclusions}

The development of novel and emerging non-thermal treatment technologies, replacing thermal technologies, has resulted from the food industry's effort to find solutions to produce healthy, safe, highly nutritious, and long shelf life foods. Non-thermal processes in relation to thermal processes have significant advantages as they require less processing time, use low temperatures and energy, increase the quality of food with improved characteristics such as color, taste, and nutrient retention, enhance their functionality, are more environmentally friendly, and lead to products with a longer shelf life. HHP has been characterized as the most successfully commercialized non-thermal processing technology, although the high cost of installation is a significant limiting factor for greater adoption of this technology by the food industry. As all processing technologies have advantages and disadvantages, the adoption of one of them in the food industry should be thoroughly considered in order to optimize all the involved parameters.

Author Contributions: Conceptualization, S.A., V.C. and T.V.; methodology, S.A., V.C. and T.V.; software, S.A., V.C. and T.V.; validation, S.A., V.C. and T.V.; formal analysis, S.A., V.C. and T.V.; investigation, S.A., V.C. and T.V.; resources, S.A., V.C. and T.V.; data curation, S.A., V.C. and T.V.; writing-original draft preparation, S.A., V.C. and T.V.; writing-review and editing, S.A., V.C. and T.V.; visualization, S.A., V.C. and T.V.; supervision, S.A., V.C. and T.V.; project administration, S.A., V.C. and T.V.; funding acquisition, S.A., V.C. and T.V. All authors have read and agreed to the published version of the manuscript. 
Funding: This research received no external funding.

Institutional Review Board Statement: Not applicable.

Informed Consent Statement: Not applicable.

Data Availability Statement: Not applicable.

Conflicts of Interest: The authors declare no conflict of interest.

\section{References}

1. Agriopoulou, S.; Stamatelopoulou, E.; Skiada, V.; Varzakas, T. Nanobiotechnology in food preservation and molecular perspective. In Book Nanotechnology-Enhanced Food Packaging, 1st ed.; Parameswaranpillai, J., Krishnankutty, R.E., Jayakumar, A., Rangappa, S.M., Siengchin, S., Eds.; Wiley-Vch GmbH: Weinheim, Germany, 2022; pp. 327-359.

2. Gizaw, Z. Public health risks related to food safety issues in the food market: A systematic literature review. Environ. Health Prev. Med. 2019, 24, 68. [CrossRef] [PubMed]

3. Roobab, U.; Aadil, R.M.; Madni, G.M.; Bekhit, A.E.D. The impact of nonthermal technologies on the microbiological quality of juices: A review. Compr. Rev. Food Sci. Food Saf. 2018, 17, 437-457. [CrossRef] [PubMed]

4. Giner, M.J.; Hizarci, Õ.; Martí, N.; Saura, D.; Valero, M. Novel approaches to reduce brown pigment formation and color changes in thermal pasteurized tomato juice. Eur. Food Res. Technol. 2013, 236, 507-515. [CrossRef]

5. Iqbal, A.; Murtaza, A.; Hu, W.; Ahmad, I.; Ahmed, A.; Xu, X. Activation and inactivation mechanisms of polyphenol oxidase during thermal and non-thermal methods of food processing. Food Bioprod. Process. 2019, 117, 170-182. [CrossRef]

6. Wang, C.Y.; Huang, H.W.; Hsu, C.P.; Yang, B.B. Recent advances in food processing using high hydrostatic pressure technology. Crit. Rev. Food Sci. Nutr. 2016, 56, 527-540. [CrossRef] [PubMed]

7. Adebo, O.A.; Molelekoa, T.; Makhuvele, R.; Adebiyi, J.A.; Oyedeji, A.B.; Gbashi, S.; Adefisoye, M.A.; Ogundele, O.M.; Njobeh, P.B. A review on novel non-thermal food processing techniques for mycotoxin reduction. Int. J. Food Sci. Technol. 2021, 56, 13-27. [CrossRef]

8. Hernández-Hernández, H.M.; Moreno-Vilet, L.; Villanueva-Rodríguez, S.J. Current status of emerging food processing technologies in Latin America: Novel non-thermal processing. Innov. Food Sci. Emerg. Technol. 2019, 58, 102233. [CrossRef]

9. López-Gámez, G.; Elez-Martínez, P.; Martín-Belloso, O.; Soliva-Fortuny, R. Recent Advances toward the application of nonthermal technologies in food processing: An insight on the bioaccessibility of health-related constituents in plant-based products. Foods 2021, 10, 1538. [CrossRef]

10. Pereira, R.N.; Vicente, A.A. Environmental impact of novel thermal and non-thermal technologies in food processing. Food Res. Int. 2010, 43, 1936-1943. [CrossRef]

11. Putnik, P.; Bursać Kovačević, D.; Herceg, K.; Pavkov, I.; Zorić, Z.; Levaj, B. Effects of modified atmosphere, anti-browning treatments and ultrasound on the polyphenolic stability, antioxidant capacity and microbial growth in fresh-cut apples. J. Food Process Eng. 2017, 40, e12539. [CrossRef]

12. Huang, D.; Men, K.; Li, D.; Wen, T.; Gong, Z.; Sunden, B.; Wu, Z. Application of ultrasound technology in the drying of food products. Ultrason. Sonochem. 2020, 63, 104950. [CrossRef]

13. Musielak, G.; Mierzwa, D.; Kroehnke, J. Food drying enhancement by ultrasound-A review. Trends Food Sci. Technol. 2016, 56, 126-141. [CrossRef]

14. Lozowicka, B.; Jankowska, M.; Hrynko, I.; Kaczynski, P. Removal of 16 Pesticide Residues from strawberries by washing with tap and ozone water, ultrasonic cleaning and boiling. Environ. Monit. Assess. 2016, 188, 1-19. [CrossRef]

15. Ramaswamy, H.S.; Awuah, G.B.; Simpson, B.K. Heat transfer and lethality considerations in aseptic processing of liquid/particle mixtures: A review. Crit. Rev. Food Sci. Nutr. 1997, 37, 253-286. [CrossRef]

16. Berk, Z. Chapter 3-Heat and mass transfer, basic principles. In Food Process Engineering and Technology, 3rd ed.; Berk, Z., Ed.; Elsevier: London, UK, 2018; pp. 79-126.

17. Vidyarthi, S.K.; Mishra, D.K.; Dolan, K.D.; Muramatsu, Y. Inverse estimation of fluid-to-particle heat transfer coefficient in aseptic processing of particulate foods. Biosyst. Eng. 2020, 198, 210-222. [CrossRef]

18. Betta, G.; Barbanti, D.; Massini, R. Food hygiene in aseptic processing and packaging system: A survey in the Italian food industry. Trends Food Sci. Technol. 2011, 22, 327e334. [CrossRef]

19. Stoforos, N.G.; Sawada, H. Aseptic processing of liquid/particulate foods. In Heat Transfer in Food Processing, WIT Transactions on State of the Art in Science and Engineering, 1st ed.; Yanniotis, S., Sundén, B., Eds.; WIT Press: Billerica, MA, USA, 2007 ; pp. 187-208.

20. FDA. Guide to Inspections of Aseptic Processing and Packaging for the Food Industry. 2014. Available online: https: //www.fda.gov/inspections-compliance-enforcement-and-criminalinvestigations/inspection-guides/aseptic-processingandpackaging-food-industry (accessed on 31 January 2022).

21. Balasubramaniam, V.M. Liquid-to-Particle Convective Heat Transfer in Aseptic Processing Systems. Ph.D. Thesis, Department of Agriculture Engineering, The Ohio State University, Columbus, OH, USA, 1993.

22. Toledo, R.T.; Singh, R.K.; Kong, F. Aseptic processing. In Fundamentals of Food Process Engineering, 4th ed.; Springer International Publishing: Cham, Switzerland, 2018; pp. 245-273. 
23. Ibrahim, M.T.; Briesen, H.; Först, P.; Zacharias, J. Lethality calculation of particulate liquid foods during aseptic processing. Processes 2019, 7, 587. [CrossRef]

24. Diep, B.; Moulin, J.; Bastic-Schmid, V.; Putallaz, T.; Gimonet, J.; Valles, A.D.; Klijn, A. Validation protocol for commercial sterility testing methods. Food Control 2019, 103, 1-8. [CrossRef]

25. Lalpuria, M.; Anantheswaran, R.; Floros, J. Packaging technologies and their role in food safety. In Microbial Decontamination in the Food Industry; Woodhead Publishing: Sawston, UK, 2012; pp. 701-745.

26. Anderson, N.M. Recent advances in low moisture food pasteurization. Curr. Opin. Food Sci. 2019, 29, 109-115. [CrossRef]

27. Hosseinzadeh Samani, B.; Khoshtaghaza, M.H.; Minaei, S.; Zareifourosh, H.; Eshtiaghi, M.N.; Rostami, S. Design, development and evaluation of an automatic fruit-juice pasteurization system using microwave-Ultrasonic waves. J. Food Sci. Technol. 2016, 53, 88-103. [CrossRef]

28. Sanchez, B.A.O.; Celestino, S.M.C.; de Abreu Gloria, M.B.; Celestino, I.C.; Lozada, M.I.O.; Júnior, S.D.A.; de Alencar, E.R.; de Oliveira, L.D.L. Pasteurization of passion fruit Passiflora setacea pulp to optimize bioactive compounds retention. Food Chem. 2020, 6, 100084. [CrossRef]

29. Zhu, X.; Guo, W.; Wu, X. Frequency-and temperature-dependent dielectric properties of fruit juices associated with pasteurization by dielectric heating. J. Food Eng. 2012, 109, 258-266. [CrossRef]

30. Lopez, A.A. Complete Course in Canning and Related Processes: Volume 3 Processing Procedures for Canned Food Products; The Canning Trade Inc.: Baltimore, MD, USA, 1987; p. 516.

31. Potter, N.N.; Hotchkiss, J.H. Food Science, 5th ed.; Springer Science+Business Media, Inc.: Berlin/Heidelberg, Germany, 1995; p. 608.

32. Tucker, G.; Featherstone, S. Essentials of Thermal Processing; John Wiley \& Sons Ltd.: Chichester, UK, $2011 ;$ p. 264.

33. Stoforos, N.G. Thermal processing. In Handbook of Food Processing: Food Preservation, 1st ed.; Varzakas, T., Tzia, C., Eds.; CRC Press, Taylor and Francis Group: Boca Raton, FL, USA, 2016; pp. 27-56.

34. Stumbo, C.R. Thermobacteriology in Food Processing, 2nd ed.; Academic Press, Inc.: Cambridge, MA, USA, 1973 ; p. 329.

35. Vajdi, M.; Pereira, R.R. Comparative effects of ethylene oxide, gamma irradiation and microwave treatments on selected spices. J. Food Sci. 1973, 38, 893-895. [CrossRef]

36. EPA: Ethylene Oxide. Agency USEP. 2017. Available online: https://www.epa.gov/stationary-sources-air-pollution/ethyleneoxide-emissions-standards-sterilization-facilities (accessed on 31 January 2022).

37. Duncan, S.E.; Moberg, K.; Amin, K.N.; Wright, M.; Newkirk, J.J.; Ponder, M.A.; Acuff, G.R.; Dickson, J.S. Processes to preserve spice and herb quality and sensory integrity during pathogen inactivation. J. Food Sci. 2017, 82, 1208-1215. [CrossRef]

38. Balchem: Propylene Oxide. 2018. Available online: https://balchem.com/performance-gases/products/propylene-oxide/ (accessed on 31 January 2022).

39. EPA: Propylene Oxide. Agency USEP. 2000. Available online: https://www.epa.gov/sites/default/files/2014-09/documents / propylene_oxide_final_volume9_2010.pdf (accessed on 31 January 2022).

40. Almela, L.; Nieto-Sandoval, J.M.; Fernández López, J.A. Microbial inactivation of paprika by a high-temperature short-X time treatment. Influence on color properties. J. Agric. Food Chem. 2002, 50, 1435-1440. [CrossRef]

41. Ivarsson, C. Nut pasteurization: Minimising impact on appearance, colour and flavor. Agro Food Ind. Hi-Tech 2011, 22, 22-24.

42. Shah, M.K.; Asa, G.; Sherwood, J.; Graber, K.; Bergholz, T.M. Efficacy of vacuum steam pasteurization for inactivation of Salmonella PT 30, Escherichia coli O157:H7 and Enterococcus faecium on low moisture foods. Int. J. Food Microbiol. 2017, 244, 111-118. [CrossRef]

43. Ban, G.H.; Kang, D.H. Effectiveness of superheated steam for inactivation of Escherichia coli O157:H7, Salmonella Typhimurium, Salmonella Enteritidis phage type 30, and Listeria monocytogenes on almonds and pistachios. Int. J. Food Microbiol. 2016, 220, 19-25. [CrossRef] [PubMed]

44. Chang, S.S.; Han, A.R.; Reyes-De-Corcuera, J.I.; Powers, J.R.; Kang, D.H. Evaluation of steam pasteurization in controlling salmonella serotype enteritidis on raw almond surfaces. Lett. Appl. Microbiol. 2010, 50, 393-398. [CrossRef] [PubMed]

45. Hou, L.; Johnson, J.A.; Wang, S. Radio frequency heating for postharvest control of pests in agricultural products: A review. Postharvest Biol. Technol. 2016, 113, 106-118. [CrossRef]

46. Marra, F.; Zhang, L.; Lyng, J.G. Radio frequency treatment of foods: Review of recent advances. J. Food Eng. 2009, 91, 497-508. [CrossRef]

47. Jeong, S.G.; Kang, D.H. Influence of moisture content on inactivation of Escherichia coli O157:H7 and Salmonella enterica serovar Typhimurium in powdered red and black pepper spices by radio-frequency heating. Int. J. Food Microbiol. 2014, 176, 15-22. [CrossRef] [PubMed]

48. Kim, S.Y.; Sagong, H.G.; Choi, S.H.; Ryu, S.; Kang, D.H. Radio-frequency heating to inactivate Salmonella Typhimurium and Escherichia coli O157:H7 on black and red pepper spice. Int. J. Food Microbiol. 2012, 153, 171-175. [CrossRef] [PubMed]

49. Schlisselberg, D.B.; Kler, E.; Kalily, E.; Kisluk, G.; Karniel, O.; Yaron, S. Inactivation of food borne pathogens in ground beef by cooking with highly controlled radio frequency energy. Int. J. Food Microbiol. 2013, 160, 219-226. [CrossRef]

50. Li, R.; Kou, X.; Cheng, T.; Zheng, A.; Wang, S. Verification of radio frequency pasteurization process for in-shell almonds. J. Food Eng. 2017, 192, 103-110. [CrossRef]

51. Awad, T.S.; Moharram, H.A.; Shaltout, O.E.; Asker, D.; Youssef, M.M. Applications of ultrasound in analysis, processing and quality control of food: A review. Food Res. Int. 2012, 48, 410-427. [CrossRef] 
52. Bhargava, N.; Mor, R.S.; Kumar, K.; Sharanagat, V.S. Advances in application of ultrasound in food processing: A review. Ultrason. Sonochem. 2021, 70, 105293. [CrossRef] [PubMed]

53. Anaya-Esparza, L.M.; Velázquez-Estrada, R.M.; Roig, A.X.; García-Galindo, H.S.; Sayago-Ayerdi, S.G.; Montalvo-González, E. Thermosonication: An Alternative Processing for Fruit and Vegetable Juices. Trends Food Sci. Technol. 2017, 61, 26-37. [CrossRef]

54. Sánchez-Rubio, M.; Taboada-Rodríguez, A.; Cava-Roda, R.; López-Gómez, A.; Marín-Iniesta, F. Combined use of thermoultrasound and cinnamon leaf essential oil to inactivate Saccharomyces Cerevisiae in natural orange and pomegranate juices. LWT Food Sci. Technol. 2016, 73, 140-146. [CrossRef]

55. Ortega-Rivas, E. Ultrasound in food preservation. Food Eng. Ser. 2012, 5, 251-262. [CrossRef]

56. Singla, M.; Sit, N. Application of ultrasound in combination with other technologies in food processing: A review. Ultrason. Sonochem. 2021, 73, 105506. [CrossRef] [PubMed]

57. Tao, Y.; Sun, D.W. Enhancement of food processes by ultrasound: A Review. Crit. Rev. Food Sci. Nutr. 2015, 55, 570-594. [CrossRef] [PubMed]

58. Rastogi, N.K. Opportunities and challenges in application of ultrasound in food processing. Crit. Rev. Food Sci. Nutr. 2011, 51, 705-722. [CrossRef] [PubMed]

59. Fu, X.; Belwal, T.; Cravotto, G.; Luo, Z. Sono-physical and sono-chemical effects of ultrasound: Primary applications in extraction and freezing operations and influence on food components. Ultrason. Sonochem. 2020, 60, 104726. [CrossRef]

60. Ojha, K.S.; Aznar, R.; O’Donnell, C.; Tiwari, B.K. Ultrasound technology for the extraction of biologically active molecules from plant, animal and marine sources. TrAC Trends Anal. Chem. 2020, 122, 115663. [CrossRef]

61. Varzakas, T.; Tzia, C. Ultrasonic and UV disinfection of food. In Handbook of Food Processing; Contemporary Food Engineering; CRC: Boca Raton, FL, USA, 2015; ISBN 13: 978-1-4987-2176-9.

62. Astráin-Redín, L.; Alejandre, M.; Raso, J.; Cebrián, G.; Álvarez, I. Direct contact ultrasound in food processing: Impact on food quality. Front. Nutr. 2021, 8, 1-11. [CrossRef]

63. Cheng, X.; Zhang, M.; Xu, B.; Adhikari, B.; Sun, J. The principles of ultrasound and its application in freezing related processes of food materials: A review. Ultrason. Sonochem. 2015, 27, 576-585. [CrossRef]

64. Deora, N.S.; Misra, N.N.; Deswal, A.; Mishra, H.N.; Cullen, P.J.; Tiwari, B.K. Ultrasound for improved crystallisation in food processing. Food Eng. Rev. 2013, 5, 36-44. [CrossRef]

65. Li, M.; Ma, F.; Li, R.; Ren, G.; Yan, D.; Zhang, H.; Zhu, X.; Wu, R.; Wu, J. Degradation of tremella fuciformis polysaccharide by a combined ultrasound and hydrogen peroxide treatment: Process parameters, structural characteristics, and antioxidant activities. Int. J. Biol. Macromol. 2020, 160, 979-990. [CrossRef]

66. Flórez-Fernández, N.; Domínguez, H.; Torres, M.D. A green approach for alginate extraction from sargassum muticum brown seaweed using ultrasound-assisted technique. Int. J. Biol. Macromol. 2019, 124, 451-459. [CrossRef]

67. Zhang, X.; Ma, X.T.; Xu, Y.; Jiang, G.C.; Zhang, J.L.; Liu, X.J.; Yan, X.H. Extraction, purification, characterization, anticoagulant activity, and anticoagulant mechanism of polysaccharides from the heads of hypomesus olidus. Food Sci. Nutr. 2020, 8, 849-861. [CrossRef] [PubMed]

68. Nuerxiati, R.; Abuduwaili, A.; Mutailifu, P.; Wubulikasimu, A.; Rustamova, N.; Jingxue, C.; Aisa, H.A.; Yili, A. Optimization of ultrasonic-assisted extraction, characterization and biological activities of polysaccharides from orchis chusua, D. Don (Salep). Int. J. Biol. Macromol. 2019, 141, 431-443. [CrossRef] [PubMed]

69. Cui, R.; Zhu, F. Ultrasound modified polysaccharides: A review of structure, physicochemical properties, biological activities and food applications. Trends Food Sci. Technol. 2021, 107, 491-508. [CrossRef]

70. Ni, Y.; Li, J.; Fan, L. Effects of ultrasonic conditions on the interfacial property and emulsifying property of cellulose nanoparticles from ginkgo seed shells. Ultrason. Sonochem. 2021, 70, 105335. [CrossRef] [PubMed]

71. Bermúdez-Aguirre, D.; Barbosa-Cánovas, G.V. Inactivation of Saccharomyces Cerevisiae in pineapple, grape and cranberry juices under pulsed and continuous thermo-sonication treatments. J. Food Eng. 2012, 108, 383-392. [CrossRef]

72. Eh, A.L.S.; Teoh, S.G. Novel modified ultrasonication technique for the extraction of lycopene from tomatoes. Ultrason. Sonochem. 2012, 19, 151-159. [CrossRef]

73. Pingret, D.; Fabiano-Tixier, A.S.; Petitcolas, E.; Canselier, J.P.; Chemat, F. First investigation on ultrasound-assisted preparation of food products: Sensory and physicochemical characteristics. J. Food Sci. 2011, 76, 287-292. [CrossRef]

74. Pingret, D.; Durand, G.; Fabiano-Tixier, A.S.; Rockenbauer, A.; Ginies, C.; Chemat, F. Degradation of edible oil during food processing by ultrasound: Electron paramagnetic resonance, physicochemical, and sensory appreciation. J. Agric. Food Chem. 2012, 60, 7761-7768. [CrossRef]

75. Pingret, D.; Fabiano-Tixier, A.S.; Chemat, F. Degradation during application of ultrasound in food processing: A review. Food Control 2013, 31, 593-606. [CrossRef]

76. Azam, S.M.R.; Ma, H.; Xu, B.; Devi, S.; Stanley, S.L.; Siddique, M.A.B.; Mujumdar, A.S.; Zhu, J. Multi-frequency multimode ultrasound treatment for removing pesticides from lettuce (Lactuca Sativa L.) and effects on product quality. LWT 2021, 143, 111147. [CrossRef]

77. Chen, F.; Zhang, M.; Yang, C.H. Application of ultrasound technology in processing of ready-to-eat fresh food: A review. Ultrason. Sonochem. 2020, 63, 104953. [CrossRef] [PubMed] 
78. Soltani Firouz, M.; Farahmandi, A.; Hosseinpour, S. Recent advances in ultrasound application as a novel technique in analysis, processing and quality control of fruits, juices and dairy products industries: A review. Ultrason. Sonochem. 2019, 57, 73-88. [CrossRef] [PubMed]

79. Liu, S.; Liu, Y.; Huang, X.; Yang, W.; Hu, W.; Pan, S. Effect of ultrasonic processing on the changes in activity, aggregation and the secondary and tertiary structure of polyphenol oxidase in oriental sweet melon (Cucumis Melo Var. Makuwa Makino). J. Sci. Food Agric. 2017, 97, 1326-1334. [CrossRef]

80. Huang, N.; Cheng, X.; Hu, W.; Pan, S. Inactivation, aggregation, secondary and tertiary structural changes of germin-like protein in satsuma mandarine with high polyphenol oxidase activity induced by ultrasonic processing. Biophys. Chem. 2015, 197, 18-24. [CrossRef] [PubMed]

81. Yeoh, W.K.; Ali, A. Ultrasound treatment on phenolic metabolism and antioxidant capacity of fresh-cut pineapple during cold storage. Food Chem. 2017, 216, 247-253. [CrossRef]

82. Costa, M.G.M.; Fonteles, T.V.; de Jesus, A.L.T.; Almeida, F.D.L.; de Miranda, M.R.A.; Fernandes, F.A.N.; Rodrigues, S. Highintensity ultrasound processing of pineapple juice. Food Bioprocess Technol. 2013, 6, 997-1006. [CrossRef]

83. Amaral, R.D.A.; Benedetti, B.C.; Pujola, M.; Achaerandio, I.; Bachelli, M.L.B. Effect of ultrasound on quality of fresh-cut potatoes during refrigerated storage. Food Eng. Rev. 2015, 7, 176-184. [CrossRef]

84. Chemat, F.; Rombaut, N.; Sicaire, A.G.; Meullemiestre, A.; Fabiano-Tixier, A.S.; Abert-Vian, M. Ultrasound Assisted Extraction of Food and Natural Products. Mechanisms, Techniques, Combinations, Protocols and Applications. A Review. Ultrason. Sonochem. 2017, 34, 540-560. [CrossRef]

85. Paniwnyk, L. Applications of ultrasound in processing of liquid foods: A review. Ultrason. Sonochem. 2017, 38, 794-806. [CrossRef]

86. Khandpur, P.; Gogate, P.R. Effect of novel ultrasound based processing on the nutrition quality of different fruit and vegetable juices. Ultrason. Sonochem. 2015, 27, 125-136. [CrossRef]

87. Ordóñez-Santos, L.E.; Martínez-Girón, J.; Arias-Jaramillo, M.E. Effect of ultrasound treatment on visual color, vitamin C, total phenols, and carotenoids content in cape gooseberry juice. Food Chem. 2017, 233, 96-100. [CrossRef] [PubMed]

88. Oladejo, A.O.; Ma, H.; Qu, W.; Zhou, C.; Wu, B.; Yang, X.; Onwude, D.I. Effects of ultrasound pretreatments on the kinetics of moisture loss and oil uptake during deep fat frying of sweet potato (Ipomea Batatas). Innov. Food Sci. Emerg. Technol. 2017, 43, 7-17. [CrossRef]

89. Dehghannya, J.; Naghavi, E.A.; Ghanbarzadeh, B. Frying of potato strips pretreated by ultrasound-assisted air-drying. J. Food Process. Preserv. 2016, 40, 583-592. [CrossRef]

90. Minakawa, A.F.K.; Faria-Tischer, P.C.S.; Mali, S. Simple ultrasound method to obtain starch micro- and nanoparticles from cassava, corn and yam Starches. Food Chem. 2019, 283, 11-18. [CrossRef]

91. Caraveo, O.; Alarcon-Rojo, A.D.; Renteria, A.; Santellano, E.; Paniwnyk, L. Physicochemical and microbiological characteristics of beef treated with high-intensity ultrasound and stored at $4{ }^{\circ} \mathrm{C}$. J. Sci. Food Agric. 2015, 95, 2487-2493. [CrossRef] [PubMed]

92. Wang, A.; Kang, D.; Zhang, W.; Zhang, C.; Zou, Y.; Zhou, G. Changes in calpain activity, protein degradation and microstructure of beef M. Semitendinosus by the application of ultrasound. Food Chem. 2018, 245, 724-730. [CrossRef] [PubMed]

93. Boateng, E.F.; Nasiru, M.M. Applications of ultrasound in meat processing technology: A review. Food Sci. Technol. USA. 2019, 7, 11-15. [CrossRef]

94. Alarcon-Rojo, A.D.; Janacua, H.; Rodriguez, J.C.; Paniwnyk, L.; Mason, T.J. Power ultrasound in meat processing. Meat Sci. 2015, 107, 86-93. [CrossRef]

95. Kang, D.C.; Wang, A.R.; Zhou, G.H.; Zhang, W.G.; Xu, S.M.; Guo, G.P. Power ultrasonic on mass transport of beef: Effects of ultrasound intensity and $\mathrm{NaCl}$ concentration. Innov. Food Sci. Emerg. Technol. 2016, 35, 36-44. [CrossRef]

96. Al-Hilphy, A.R.; Al-Temimi, A.B.; Al Rubaiy, H.H.M.; Anand, U.; Delgado-Pando, G.; Lakhssassi, N. Ultrasound applications in poultry meat processing: A systematic review. J. Food Sci. 2020, 85, 1386-1396. [CrossRef]

97. Kang, D.-C.; Gao, X.-Q.; Ge, Q.-F.; Zhou, G.-H.; Zhang, W.-G. Effects of ultrasound on the beef structure and water distribution during curing through protein degradation and modification. Ultrason. Sonochem. 2017, 38, 317-325. [CrossRef]

98. Peña-Gonzalez, E.; Alarcon-Rojo, A.D.; Garcia-Galicia, I.; Carrillo-Lopez, L.; Huerta-Jimenez, M. Ultrasound as a potential process to tenderize beef: Sensory and technological parameters. Ultrason. Sonochem. 2019, 53, 134-141. [CrossRef]

99. Chang, H.J.; Xu, X.L.; Zhou, G.H.; Li, C.B.; Huang, M. Effects of characteristics changes of collagen on meat physicochemical properties of beef semitendinosus muscle during ultrasonic processing. Food Bioprocess Technol. 2012, 5, 285-297. [CrossRef]

100. Hu, Y.; Yu, H.; Dong, K.; Yang, S.; Ye, X.; Chen, S. Analysis of the tenderisation of jumbo squid (Dosidicus Gigas) meat by ultrasonic treatment using response surface methodology. Food Chem. 2014, 160, 219-225. [CrossRef]

101. Zhu, F.; Li, H. Modification of quinoa flour functionality using ultrasound. Ultrason. Sonochem. 2019, 52, 305-310. [CrossRef]

102. Fox, P.; Smith, P.P.; Sahi, S. Ultrasound measurements to monitor the specific gravity of food batters. J. Food Eng. 2004, 65, 317-324. [CrossRef]

103. Ding, J.; Hou, G.G.; Dong, M.; Xiong, S.; Zhao, S.; Feng, H. Physicochemical properties of germinated dehulled rice flour and energy requirement in germination as affected by ultrasound treatment. Ultrason. Sonochem. 2018, 41, 484-491. [CrossRef]

104. Harasym, J.; Satta, E.; Kaim, U. Ultrasound treatment of buckwheat grains impacts important functional properties of resulting flour. Molecules 2020, 25, 3012. [CrossRef]

105. Zhang, H.; Chen, G.; Liu, M.; Mei, X.; Yu, O.; Kan, J. Effects of multi-frequency ultrasound on physicochemical properties, structural characteristics of gluten protein and the quality of noodle. Ultrason. Sonochem. 2020, 67, 105-135. [CrossRef] 
106. Guimarães, J.T.; Balthazar, C.F.; Scudino, H.; Pimentel, T.C.; Esmerino, E.A.; Ashokkumar, M.; Freitas, M.Q.; Cruz, A.G. Highintensity ultrasound: A novel technology for the development of probiotic and prebiotic dairy products. Ultrason. Sonochem. 2019, 57, 12-21. [CrossRef]

107. Huang, G.; Chen, S.; Tang, Y.; Dai, C.; Sun, L.; Ma, H.; He, R. Stimulation of low intensity ultrasound on fermentation of skim milk medium for yield of yoghurt peptides by Lactobacillus paracasei. Ultrason. Sonochem. 2019, 51, 315-324. [CrossRef]

108. Umego, E.C.; He, R.; Huang, G.; Dai, C.; Ma, H. Ultrasound-assisted fermentation: Mechanisms, technologies, and challenges. J. Food Process. Preserv. 2021, 45, e15559. [CrossRef]

109. Shanmugam, A.; Chandrapala, J.; Ashokkumar, M. The effect of ultrasound on the physical and functional properties of skim milk. Innov. Food Sci. Emerg. Technol. 2012, 16, 251-258. [CrossRef]

110. Akdeniz, V.; Akalın, A.S. New approach for yoghurt and ice cream production: High-intensity ultrasound. Trends Food Sci. Technol. 2019, 86, 392-398. [CrossRef]

111. Carpenter, J.; Saharan, V.K. Ultrasonic assisted formation and stability of mustard oil in water nanoemulsion: Effect of process parameters and their optimization. Ultrason. Sonochem. 2017, 35, 422-430. [CrossRef]

112. Albano, K.M.; Nicoletti, V.R. Ultrasound impact on whey protein concentrate-pectin complexes and in the O/W emulsions with low oil soybean content stabilization. Ultrason. Sonochem. 2018, 41, 562-571. [CrossRef]

113. Gayán, E.; Condón, S.; Álvarez, I. Biological aspects in food preservation by ultraviolet light: A review. Food Bioprocess Technol. 2014, 7, 1-20. [CrossRef]

114. Koutchma, T.N.; Forney, L.J.; Moraru, C.I. Ultraviolet Light in Food Technology Principles and Applications, 2009th ed.; Sun, D.-W., Ed.; CRC: Boca Raton, FL, USA, 2009; ISBN 13: 978-1-4200-5950-2.

115. Ramesh, T.; Nayak, B.; Amirbahman, A.; Tripp, C.P.; Mukhopadhyay, S. Application of ultraviolet light assisted titanium dioxide photocatalysis for food safety: A review. Innov. Food Sci. Emerg. Technol. 2016, 38, 105-115. [CrossRef]

116. Yoo, S.; Ghafoor, K.; Kim, J.U.; Kim, S.; Jung, B.; Lee, D.U.; Park, J. Inactivation of Escherichia coli O157:H7 on orange fruit surfaces and in juice using photocatalysis and high hydrostatic pressure. J. Food Prot. 2015, 78, 1098-1105. [CrossRef]

117. Shahbaz, H.M.; Yoo, S.; Seo, B.; Ghafoor, K.; Kim, J.U.; Lee, D.U.; Park, J. Combination of TiO ${ }_{2}$-UV photocatalysis and high hydrostatic pressure to inactivate bacterial pathogens and yeast in commercial apple juice. Food Bioprocess Technol. 2016, 9, 182-190. [CrossRef]

118. Corrêa, T.Q.; Blanco, K.C.; Garcia, É.B.; Perez, S.M.L.; Chianfrone, D.J.; Morais, V.S.; Bagnato, V.S. Effects of ultraviolet light and curcumin-mediated photodynamic inactivation on microbiological food safety: A study in meat and fruit. Photodiagnosis Photodyn. Ther. 2020, 30, 101678. [CrossRef]

119. Orlowska, M.; Koutchma, T.; Grapperhaus, M.; Gallagher, J.; Schaefer, R.; Defelice, C. Continuous and pulsed ultraviolet light for nonthermal treatment of liquid foods. Part 1: Effects on quality of fructose solution, apple juice, and milk. Food Bioprocess Technol. 2013, 6, 1580-1592. [CrossRef]

120. Gayán, E.; Serrano, M.J.; Monfort, S.; Álvarez, I.; Condón, S. Combining ultraviolet light and mild temperatures for the inactivation of Escherichia coli in orange juice. J. Food Eng. 2012, 113, 598-605. [CrossRef]

121. Ochoa-Velasco, C.E.; Cruz-González, M.; Guerrero-Beltrán, J.Á. Ultraviolet-C light inactivation of Escherichia coli and Salmonella typhimurium in coconut (Cocos nucifera L.) milk. Innov. Food Sci. Emerg. Technol. 2014, 26, 199-204. [CrossRef]

122. Fredericks, I.N.; du Toit, M.; Krügel, M. Efficacy of ultraviolet radiation as an alternative technology to inactivate microorganisms in grape juices and wines. Food Microbiol. 2011, 28, 510-517. [CrossRef]

123. Hinds, L.M.; Guclu, G.; Kelebek, H.; Selli, S.; O’Donnell, C.P.; Tiwari, B.K. Effect of ultraviolet light emitting diode treatments on microbial load, phenolic and volatile profile of black peppercorns. LWT 2021, 152, 112133. [CrossRef]

124. Nyhan, L.; Przyjalgowski, M.; Lewis, L.; Begley, M.; Callanan, M. Investigating the use of ultraviolet light emitting diodes (UV-Leds) for the inactivation of bacteria in powdered food ingredients. Foods 2021, 10, 797. [CrossRef]

125. Baenas, N.; Iniesta, C.; González-Barrio, R.; Nuñez-Gómez, V.; Periago, M.J.; García-Alonso, F.J. Post-harvest use of ultraviolet light (UV) and light emitting diode (LED) to enhance bioactive compounds in refrigerated tomatoes. Molecules 2021, $26,1847$. [CrossRef]

126. Lázaro, C.A.; Conte-Júnior, C.A.; Monteiro, M.L.G.; Canto, A.C.V.S.; Costa-Lima, B.R.C.; Mano, S.B.; Franco, R.M. Effects of ultraviolet light on biogenic amines and other quality indicators of chicken meat during refrigerated storage. Poult. Sci. 2014, 93, 2304-2313. [CrossRef]

127. Colejo, S.; Alvarez-Ordóñez, A.; Prieto, M.; González-Raurich, M.; López, M. Evaluation of ultraviolet light (UV), non-thermal atmospheric plasma (NTAP) and their combination for the control of foodborne pathogens in smoked salmon and their effect on quality attributes. Innov. Food Sci. Emerg. Technol. 2018, 50, 84-93. [CrossRef]

128. Konak, Ü.I.; Certel, M.; Karakaş, B. Effects of ultraviolet irradiation of batter and different baking methods on cake quality. J. Microbiol. Biotechnol. Food Sci. 2017, 7, 113-117. [CrossRef]

129. Kumar, A.; Rani, P.; Purohit, S.R.; Rao, P.S. Effect of ultraviolet irradiation on wheat (Triticum aestivum) flour: Study on protein modification and changes in quality attributes. J. Cereal Sci. 2020, 96, 103094. [CrossRef]

130. Guneser, O.; Karagul Yuceer, Y. Effect of ultraviolet light on water- and fat-soluble vitamins in cow and goat milk. J. Dairy Sci. 2012, 95, 6230-6241. [CrossRef]

131. Koca, N.; Öztürk, M.U. Application of batch system ultraviolet light on the surface of kashar cheese, a kind of pasta-filata cheese: Effects on mould inactivation, lipid oxidation, colour, hardness and sensory properties. J. Dairy Res. 2020, 87, 493-497. [CrossRef] 
132. Ricciardi, E.F.; Pedros-Garrido, S.; Papoutsis, K.; Lyng, J.G.; Conte, A.; Del Nobile, M.A. Novel technologies for preserving ricotta cheese: Effects of ultraviolet and near-ultraviolet-visible light. Foods 2020, 9, 580. [CrossRef]

133. Ha, J.W.; Back, K.H.; Kim, Y.H.; Kang, D.H. Efficacy of UV-C Irradiation for inactivation of food-borne pathogens on sliced cheese packaged with different types and thicknesses of plastic films. Food Microbiol. 2016, 57, 172-177. [CrossRef]

134. Casas, D.E.; Vargas, D.A.; Randazzo, E.; Lynn, D.; Echeverry, A.; Brashears, M.M.; Sanchez-Plata, M.X.; Miller, M.F. In-plant validation of novel on-site ozone generation technology (bio-safe) compared to lactic acid beef carcasses and trim using natural microbiota and Salmonella and E. coli O157:H7 surrogate enumeration. Foods 2021, 10, 1002. [CrossRef]

135. Liao, C.; Yu, Y. Effect of vacuum cooling followed by ozone repressurization on Clostridium perfringens germination and outgrowth in cooked pork meat under temperature-sbuse conditions. Innov. Food Sci. Emerg. Technol. 2021, 68, 102599. [CrossRef]

136. Megahed, A.; Aldridge, B.; Lowe, J. Antimicrobial efficacy of aqueous ozone and ozone-lactic acid blend on SalmonellaContaminated chicken drumsticks using multiple sequential soaking and spraying approaches. Front. Microbiol. 2020, 11,1-11. [CrossRef]

137. Li, Z.; Sun, Y.; Jin, H.; Wang, Q.; Jin, Y.; Huang, X.; Sheng, L. Improvement and mechanism of emulsifying properties of liquid egg yolk by ozonation technology. LWT 2022, 156, 113038. [CrossRef]

138. Bono, G.; Okpala, C.O.R.; Vitale, S.; Ferrantelli, V.; Noto, A.D.; Costa, A.; Di Bella, C.; Monaco, D.L. Effects of different ozonized slurry-ice treatments and superchilling storage $\left(-1^{\circ} \mathrm{C}\right)$ on microbial spoilage of two important pelagic fish species. Food Sci. Nutr. 2017, 5, 1049-1056. [CrossRef]

139. Traore, M.B.; Sun, A.; Gan, Z.; Senou, H.; Togo, J.; Fofana, K.H. Antimicrobial capacity of ultrasound and ozone for enhancing bacterial safety on inoculated shredded green cabbage (Brassica oleracea Var. capitata). Can. J. Microbiol. 2020, 66, 125-137. [CrossRef]

140. Taiye Mustapha, A.; Zhou, C.; Wahia, H.; Amanor-Atiemoh, R.; Otu, P.; Qudus, A.; Abiola Fakayode, O.; Ma, H. Sonozonation: Enhancing the antimicrobial efficiency of aqueous ozone washing techniques on cherry tomato. Ultrason. Sonochem. 2020, 64, 105059. [CrossRef]

141. De Souza, L.P.; Faroni, L.R.D.A.; Heleno, F.F.; Cecon, P.R.; Gonçalves, T.D.C.; da Silva, G.J.; Prates, L.H.F. Effects of ozone treatment on postharvest carrot quality. LWT Food Sci. Technol. 2018, 90, 53-60. [CrossRef]

142. Kusvuran, E.; Yildirim, D.; Mavruk, F.; Ceyhan, M. Removal of chloropyrifos ethyl, tetradifon and chlorothalonil pesticide residues from citrus by using ozone. J. Hazard. Mater. 2012, 241-242, 287-300. [CrossRef]

143. García-Martínez, M.M.; Campayo, A.; Carot, J.M.; de la Hoz, K.S.; Salinas, M.R.; Alonso, G.L. Oenological characteristics of Vitis Vinifera L. cabernet sauvignon grapes from vineyards treated with ozonated water. Aust. J. Grape Wine Res. 2020, 26, 388-398. [CrossRef]

144. Flores, P.; Hernández, V.; Fenoll, J.; Hellín, P. Pre-harvest application of ozonated water on broccoli crops: Effect on head quality. J. Food Compos. Anal. 2019, 83, 103260. [CrossRef]

145. Aslam, R.; Alam, M.S.; Pandiselvam, R. Aqueous ozone sanitization system for fresh produce: Design, development, and optimization of process parameters for minimally processed onion. Ozone Sci. Eng. 2022, 44, 3-16. [CrossRef]

146. Panigrahi, C.; Mishra, H.N.; De, S. Ozone treatment of ultrafiltered sugarcane juice: Process optimization using multi-objective genetic algorithm and correlation analysis by multivariate technique. LWT Food Sci. Technol. 2022, 154, 112861. [CrossRef]

147. Ouf, S.A.; Ali, E.M. Does the treatment of dried herbs with ozone as a fungal decontaminating agent affect the active constituents? Environ. Pollut. 2021, 277, 116715. [CrossRef]

148. Matłok, N.; Piechowiak, T.; Zardzewiały, M.; Gorzelany, J.; Balawejder, M. Effects of ozone treatment on microbial status and the contents of selected bioactive compounds in Origanum majorana L. plants. Plants 2020, 9, 1637. [CrossRef]

149. Alexopoulos, A.; Plessas, S.; Kourkoutas, Y.; Stefanis, C.; Vavias, S.; Voidarou, C.; Mantzourani, I.; Bezirtzoglou, E. Experimental effect of ozone upon the microbial flora of commercially produced dairy fermented products. Int. J. Food Microbiol. 2017, 246, 5-11. [CrossRef]

150. Sachadyn-Król, M.; Agriopoulou, S. Ozonation as a method of abiotic elicitation improving the health-Promoting properties of plant products-A review. Molecules 2020, 25, 2416. [CrossRef]

151. Pandiselvam, R.; Manikantan, M.R.; Divya, V.; Ashokkumar, C.; Kaavya, R.; Kothakota, A.; Ramesh, S.V. Ozone: An advanced oxidation technology for starch modification. Ozone Sci. Eng. 2019, 41, 491-507. [CrossRef]

152. García-Mateos, M.R.; Quiroz-González, B.; Corrales-García, J.; Ybarra-Moncada, C.; Leyva-Ruelas, G. Ozone-high hydrostatic pressure synergy for the stabilization of refrigerated pitaya (Stenocereus pruinosus) juice. Innov. Food Sci. Emerg. Technol. 2019, 56, 102187. [CrossRef]

153. Marino, M.; Maifreni, M.; Baggio, A.; Innocente, N. Inactivation of foodborne bacteria biofilms by aqueous and gaseous ozone. Front. Microbiol. 2018, 9, 1-12. [CrossRef]

154. Sivaranjani, S.; Prasath, V.A.; Pandiselvam, R.; Kothakota, A.; Mousavi Khaneghah, A. Recent advances in applications of ozone in the cereal industry. LWT Food Sci. Technol. 2021, 146, 111412. [CrossRef]

155. Agriopoulou, S.; Stamatelopoulou, E.; Varzakas, T. Advances in occurrence, importance, and mycotoxin control strategies: Prevention and detoxification in foods. Foods 2020, 9, 137. [CrossRef]

156. Agriopoulou, S.; Koliadima, A.; Karaiskakis, G.; Kapolos, J. Kinetic study of aflatoxins' degradation in the presence of ozone. Food Control 2016, 61, 221-226. [CrossRef] 
157. Sujayasree, O.J.; Chaitanya, A.K.; Bhoite, R.; Pandiselvam, R.; Kothakota, A.; Gavahian, M.; Mousavi Khaneghah, A. Ozone: An advanced oxidation technology to enhance sustainable food consumption through mycotoxin degradation. Ozone Sci. Eng. 2022, 44, 17-37. [CrossRef]

158. Agriopoulou, S.; Stamatelopoulou, E.; Varzakas, T. Advances in analysis and detection of major mycotoxins in foods. Foods 2020, 9, 518. [CrossRef]

159. Bermúdez-Aguirre, D.; Barbosa-Cánovas, G.V. Ozone applications in food processing. In Handbook of Food Processing: Food Preservation, 1st ed.; Varzakas, T., Tzia, C., Eds.; CRC Press, Taylor and Francis Group: Boca Raton, FL, USA, 2016 ; pp. 691-704.

160. Kaavya, R.; Pandiselvam, R.; Abdullah, S.; Sruthi, N.U.; Jayanath, Y.; Ashokkumar, C.; Chandra Khanashyam, A.; Kothakota, A.; Ramesh, S.V. Emerging non-thermal technologies for decontamination of salmonella in food. Trends Food Sci. Technol. 2021, 112, 400-418. [CrossRef]

161. Pandiselvam, R.; Subhashini, S.; Banuu Priya, E.P.; Kothakota, A.; Ramesh, S.V.; Shahir, S. Ozone based food preservation: A promising green technology for enhanced food safety. Ozone Sci. Eng. 2019, 41, 17-34. [CrossRef]

162. Niveditha, A.; Pandiselvam, R.; Prasath, V.A.; Singh, S.K.; Gul, K.; Kothakota, A. Application of cold plasma and ozone technology for decontamination of Escherichia coli in foods-A review. Food Control 2021, 130, 108338. [CrossRef]

163. Premjit, Y.; Sruthi, N.U.; Pandiselvam, R.; Kothakota, A. Aqueous ozone: Chemistry, physicochemical properties, microbial inactivation, factors influencing antimicrobial effectiveness, and application in food. Compr. Rev. Food Sci. Food Saf. 2022, 20, 1-32. [CrossRef]

164. Pandiselvam, R.; Sunoj, S.; Manikantan, M.R.; Kothakota, A.; Hebbar, K.B. Application and kinetics of ozone in food preservation. Ozone Sci. Eng. 2017, 39, 115-126. [CrossRef]

165. Yucel Sengun, I.; Kendirci, P. Potential of ozonated water at different temperatures to improve safety and shelf-life of fresh cut lettuce. Ozone Sci. Eng. 2018, 40, 216-227. [CrossRef]

166. Wani, S.; Maker, J.; Thompson, J.; Barnes, J.; Singleton, I. Effect of ozone treatment on inactivation of Escherichia coli and Listeria Sp. on spinach. Agriculture 2015, 5, 155-169. [CrossRef]

167. Siddique, Z.; Malik, A.U.; Asi, M.R.; Anwar, R.; Inam Ur Raheem, M. Sonolytic-ozonation technology for sSanitizing microbial contaminants and pesticide residues from spinach (Spinacia Oleracea L.) leaves, at household level. Environ. Sci. Pollut. Res. 2021, 28, 52913-52924. [CrossRef]

168. Ummat, V.; Singh, A.K.; Sidhu, G.K. Effect of aqueous ozone on quality and shelf life of shredded green bell pepper (Capsicum annuum). J. Food Process. Preserv. 2018, 42,1-14. [CrossRef]

169. Nayak, S.L.; Sethi, S.; Sharma, R.R.; Sharma, R.M.; Singh, S.; Singh, D. Aqueous ozone controls decay and maintains quality attributes of strawberry (Fragaria $\times$ Ananassa Duch.). J. Food Sci. Technol. 2020, 57, 319-326. [CrossRef] [PubMed]

170. Contigiani, E.V.; Kronberg, M.F.; Jaramillo Sánchez, G.; Gómez, P.L.; García-Loredo, A.B.; Munarriz, E.; Alzamora, S.M. Ozone washing decreases strawberry susceptibility to Botrytis cinerea while maintaining antioxidant, optical and sensory quality. Heliyon 2020, 6, e05416. [CrossRef] [PubMed]

171. Liu, C.; Chen, C.; Jiang, A.; Zhang, Y.; Zhao, Q.; Hu, W. Effects of aqueous ozone treatment on microbial growth, quality, and pesticide residue of fresh-cut cabbage. Food Sci. Nutr. 2021, 9, 52-61. [CrossRef] [PubMed]

172. Chen, C.; Liu, C.; Jiang, A.; Zhao, Q.; Liu, S.; Hu, W. Effects of ozonated water on microbial growth, quality retention and pesticide residue removal of fresh-cut onions. Ozone Sci. Eng. 2020, 42, 399-407. [CrossRef]

173. Gonçalves, A.A.; Lira Santos, T.C. Improving quality and shelf-life of whole chilled pacific white shrimp (Litopenaeus vannamei) by ozone technology combined with modified atmosphere packaging. LWT 2019, 99, 568-575. [CrossRef]

174. Giannoglou, M.; Dimitrakellis, P.; Efthimiadou, A.; Gogolides, E.; Katsaros, G. Comparative study on the effect of cold atmospheric plasma, ozonation, pulsed electromagnetic fields and high-pressure technologies on sea bream fillet quality indices and shelf life. Food Eng. Rev. 2021, 13, 175-184. [CrossRef]

175. López Hernández, K.; Pardío Sedas, V.; Rodríguez Dehaibes, S.; Suárez Valencia, V.; Rivas Mozo, I.; Martínez Herrera, D.; Flores Primo, A.; Uscanga Serrano, R. Improved microbial safety of direct ozone-depurated shellstock Eastern oysters (Crassostrea virginica) by superchilled storage. Front Microbiol. 2018, 9, 2802. [CrossRef]

176. Zalewska, M.; Górska-Horczyczak, E.; Marcinkowska-Lesiak, M. Effect of Applied Ozone Dose, Time of Ozonization and Storage Time on Selected Physicochemical Characteristics of Mushrooms (Agaricus bisporus). Agriculture 2021, 11, 748. [CrossRef]

177. Ayranci, U.G.; Ozunlu, O.; Ergezer, H.; Karaca, H. Effects of ozone treatment on microbiological quality and physicochemical properties of turkey breast meat. Ozone Sci. Eng. 2020, 42, 95-103, 541. [CrossRef]

178. Giménez, B.; Graiver, N.; Giannuzzi, L.; Zaritzky, N. Treatment of beef with gaseous ozone: Physicochemical aspects and antimicrobial effects on heterotrophic microflora and Listeria monocytogenes. Food Control 2021, 121, 1-9. [CrossRef]

179. Degala, H.L.; Scott, J.R.; Rico Espinoza, F.I.; Mahapatra, A.K.; Kannan, G. Synergistic effect of ozonated and electrolyzed water on the inactivation kinetics of Escherichia coli on goat meat. J. Food Saf. 2020, 40, e12740. [CrossRef]

180. Jaramillo Sánchez, G.M.; Garcia Loredo, A.B.; Contigiani, E.V.; Gómez, P.L.; Alzamora, S.M. Inactivation kinetics of peroxidase and polyphenol oxidase in peach juice treated with gaseous ozone. Int. J. Food Sci. Technol. 2018, 53, 347-355. [CrossRef]

181. Patil, S.; Valdramidis, V.P.; Tiwari, B.K.; Cullen, P.J.; Bourke, P. Quantitative assessment of the shelf life of ozonated apple juice. Eur. Food Res. Technol. 2011, 232, 469-477. [CrossRef]

182. Timpanaro, N.; Strano, M.C.; Allegra, M.; Foti, P.; Granuzzo, G.; Carboni, C.; Romeo, F.V. Assessing the effect of ozonated water on microbial load and quality of Nocellara Etnea table olives. Ozone Sci. Eng. 2021, 43, 1-8. [CrossRef] 
183. Werlang, G.O.; Kich, J.D.; Lopes, G.V.; Coldebella, A.; Feddern, V.; Cardoso, M. Effect of gaseous ozone application during chilling on microbial and quality attributes of pig carcasses. Food Sci. Technol. Int. 2021, 27, 10820132211014985. [CrossRef] [PubMed]

184. Khanashyam, A.C.; Shanker, M.A.; Kothakota, A.; Mahanti, N.K.; Pandiselvam, R. Ozone applications in milk and meat industry. Ozone Sci. Eng. 2021, 44, 1-16. [CrossRef]

185. Muhlisin, M.; Utama, D.T.; Lee, J.H.; Choi, J.H.; Lee, S.K. Effects of gaseous ozone exposure on bacterial counts and oxidative properties in chicken and duck breast meat. Korean J. Food Sci. Anim. Resour. 2016, 36, 405-411. [CrossRef]

186. Aganovic, K.; Hertel, C.; Vogel, R.F.; Johne, R.; Schlüter, O.; Schwarzenbolz, U.; Jäger, H.; Holzhauser, T.; Bergmair, J.; Roth, A.; et al. Aspects of high hydrostatic pressure food processing: Perspectives on technology and food safety. Compr. Rev. Food Sci. Food Saf. 2021, 20, 3225-3266. [CrossRef]

187. Tsikrika, K.; Walsh, D.; Joseph, A.; Burgess, C.M.; Rai, D.K. High-pressure processing and ultrasonication of minimally processed potatoes: Effect on the colour, microbial counts, and bioactive compounds. Molecules 2021, 26, 2614. [CrossRef]

188. Cano-Lamadrid, M.; Artés-Hernández, F. By-products revalorization with non-thermal treatments to enhance phytochemical compounds of fruit and vegetables derived products: A review. Foods 2022, 11, 59. [CrossRef]

189. Morata, A.; Escott, C.; Loira, I.; López, C.; Palomero, F.; González, C. Emerging non-thermal technologies for the extraction of grape anthocyanins. Antioxidants 2021, 10, 1863. [CrossRef]

190. Ozkan, G.; Guldiken, B.; Capanoglu, E. Effect of novel food processing technologies on beverage antioxidants. In Processing and Sustainability of Beverages; Grumezescu, A.M., Holban, A.M., Eds.; Woodhead Publishing: Cambridge, UK, 2019 ; pp. 413-449.

191. Roobab, U.; Shabbir, M.A.; Khan, A.W.; Arshad, R.N.; Bekhit, A.E.; Zeng, X.A.; Inam-Ur-Raheem, M.; Aadil, R.M. High-pressure treatments for better quality clean-label juices and beverages: Overview and advances. LWT Food Sci. Technol. 2021, 149, 111828. [CrossRef]

192. Balakrishna, A.K.; Wazed, M.A.; Farid, M. A Review on the effect of high pressure processing (HPP) on gelatinization and infusion of nutrients. Molecules 2020, 25, 2369. [CrossRef] [PubMed]

193. Katsaros, G.; Alexandrakis, Z.; Taoukis, P. High-pressure processing of foods: Technology and applications. In Handbook of Food Processing: Food Preservation, 1st ed.; Varzakas, T., Tzia, C., Eds.; CRC Press, Taylor and Francis Group: Boca Raton, FL, USA, 2016; pp. $443-468$.

194. Barba, F.J.; Terefe, N.S.; Buckow, R.; Knorr, D.; Orlien, V. New opportunities and perspectives of high pressure treatment to improve health and safety attributes of foods. A review. Food Res. Int. 2015, 77, 725-742. [CrossRef]

195. Woldemariam, H.W.; Emire, S.A. High pressure processing of foods for microbial and mycotoxins control: Current trends and future prospects. Cogent Food Agric. 2019, 5, 1622184. [CrossRef]

196. Balasubramaniam, V.M.; Martinez-Monteagudo, S.I.; Gupta, R. Principles and application of high pressure-based technologies in the food industry. Ann. Rev. Food Sci. Technol. 2015, 6, 435-462. [CrossRef]

197. Huang, H.W.; Hsu, C.P.; Wang, C.Y. Healthy expectations of high hydrostatic pressure treatment in food processing industry. J. Food Drug Anal. 2020, 28, 1-13. [CrossRef] [PubMed]

198. Škegro, M.; Putnik, P.; Bursać Kovačević, D.; Kovač, A.P.; Salkić, L.; Čanak, I.; Frece, J.; Zavadlav, S.; Ježek, D. Chemometric comparison of high-pressure processing and thermal pasteurization: The nutritive, sensory, and microbial quality of smoothies. Foods 2021, 10, 1167. [CrossRef] [PubMed]

199. Gavahian, M.; Mathad, G.N.; Pandiselvam, R.; Lin, J.; Sun, D.-W. Emerging technologies to obtain pectin from food processing by-products: A strategy for enhancing resource efficiency. Trends Food Sci. Technol. 2021, 115, 42-54. [CrossRef]

200. Huang, H.W.; Wu, S.J.; Lu, J.K.; Shyu, Y.T.; Wang, C.Y. Current status and future trends of high-pressure processing in food industry. Food Control 2017, 72, 1-8. [CrossRef]

201. Amsasekar, A.; Mor, R.S.; Kishore, A.; Singh, A.; Sid, S. Impact of high pressure processing on microbiological, nutritional and sensory properties of food: A review. Nutr. Food Sci. 2022, 52, 1-22. [CrossRef]

202. Agriopoulou, S.; Stamatelopoulou, E.; Sachadyn-Król, M.; Varzakas, T. Lactic acid bacteria as antibacterial agents to extend the shelf life of fresh and minimally processed fruits and vegetables: Quality and safety aspects. Microorganisms 2020, 8, 952. [CrossRef] [PubMed]

203. Kyriacou, M.C.; Rouphael, Y. Towards a new definition of quality for fresh fruits and vegetables. Sci. Hortic. 2018, 234, 463-469. [CrossRef]

204. Corato, U.D. Improving the shelf- life and quality of fresh and minimally- processed fruits and vegetables for a modern food industry: A comprehensive critical review from the traditional technologies into the most promising advancements. Crit. Rev. Food Sci. Nutr. 2020, 60, 940-975. [CrossRef]

205. Baranda, A.B.; Montes, P. HPP for improving preservation of vitamin and antioxidant contents in vegetable matrices. In Present and Future of High Pressure Processing: A Tool for Developing Innovative, Sustainable, Safe and Healthy Foods; Barba, F.J., Tonello-Samson, C., Puértolas, E., Lavilla, M., Eds.; Elsevier: Amsterdam, The Netherlands, 2020; pp. 15-70.

206. Viacava, F.; Ortega, E.; Welti-Chanes, J.; Cisneros-Zevallos, L.; Jacobo-Velázquez, D.A. Using high hydrostatic pressure processing come-up time as an innovative tool to induce the biosynthesis of free and bound phenolics in whole carrots. Food Bioprocess Technol. 2020, 13, 1717-1727. [CrossRef]

207. Jacobo-Velázquez, D.A.; Benavides, J. Non-thermal technologies as tools to increase the content of health-promoting compounds in whole fruits and vegetables while retaining quality attributes. Foods 2021, 10, 2904. [CrossRef] 
208. Nabi, B.G.; Mukhtar, K.; Arshad, R.N.; Radicetti, E.; Tedeschi, P.; Shahbaz, M.U.; Walayat, N.; Nawaz, A.; Inam-Ur-Raheem, M.; Aadil, R.M. High-pressure processing for sustainable food supply. Sustainability 2021, 13, 13908. [CrossRef]

209. Hu, K.; Peng, D.; Wang, L.; Liu, H.; Xie, B.; Sun, Z. Effect of mild high hydrostatic pressure treatments on physiological and physicochemical characteristics and carotenoid biosynthesis in postharvest mango. Postharvest Biol. Technol. 2021, $172,111381$. [CrossRef]

210. Kim, T.; Gil, B.; Kim, C.; Cho, Y. Enrichment of phenolics in harvested strawberries by high-pressure treatment. Food Bioprocess Technol. 2017, 10, 222-227. [CrossRef]

211. Morata, A.; Loira, I.; Vejarano, R.; Bañuelos, M.A.; Sanz, P.D.; Otero, L.; Suárez-Lepe, J.A. Grape processing by high hydrostaticPressure: Effect on microbial populations, phenol extraction and wine quality. Food Bioprocess Technol. 2014, 8, 277-286. [CrossRef]

212. Ninčević Grassino, A.; Ostojić, J.; Miletić, V.; Djaković, S.; Bosiljkov, T.; Zorić, Z.; Ježek, D.; Rimac Brnčić, S.; Brnčić, M. Application of high hydrostatic pressure and ultrasound-assisted extractions as a novel approach for pectin and polyphenols recovery from tomato peel waste. Innov. Food Sci. Emerg. Technol. 2020, 64, 102424. [CrossRef]

213. Strati, I.F.; Gogou, E.; Oreopoulou, V. Enzyme and high pressure assisted extraction of carotenoids from tomato waste. Food Bioprod. Process. 2015, 94, 668-674. [CrossRef]

214. Xie, F.; Zhang, W.; Lan, X.; Gong, S.; Wu, J.; Wang, Z. Effects of high hydrostatic pressure and high pressure homogenization processing on characteristics of potato peel waste pectin. Carbohydr. Polym. 2018, 196, 474-482. [CrossRef] [PubMed]

215. Boziaris, I.S.; Parlapani, F.F.; DeWitt, C.A.M. High pressure processing at ultra-low temperatures: Inactivation of foodborne bacterial pathogens and quality changes in frozen fish fillets. Innov. Food Sci. Emerg. Technol. 2021, 74, 102811. [CrossRef]

216. Bechstein, D.V.; Popp, J.; Sudhaus-Joern, N.; Krischek, C. Effect of ethyl-lauroyl-arginate hypochloride in combination with high hydrostatic pressure processing on the microbial load and physico-chemical characteristics of minced and portioned chicken breast meat. Poult Sci. 2019, 98, 966-976. [CrossRef]

217. Sheen, S.; Huang, C.-Y.; Ramos, R.; Chien, S.-Y.; Scullen, O.J.; Sommers, C. Lethality prediction for Escherichia coli O157:H7 and uropathogenic E. coli in ground chicken treated with high pressure processing and trans-cinnamaldehyde. J. Food Sci. 2018, 83, 740-749. [CrossRef]

218. Possas, A.; Pérez-Rodríguez, F.; Valero, A.; García-Gimeno, R.M. Modelling the inactivation of Listeria monocytogenes by high hydrostatic pressure processing in foods: A review. Trends Food Sci. Technol. 2017, 70, 45-55. [CrossRef]

219. Cava, R.; Higuero, N.; Ladero, L. High-pressure processing and storage temperature on Listeria monocytogenes, microbial counts and oxidative changes of two traditional dry-cured meat products. Meat Sci. 2021, 171, 108273. [CrossRef] [PubMed]

220. Argyri, A.A.; Papadopoulou, O.S.; Nisiotou, A.; Tassou, C.C.; Chorianopoulos, N. Effect of high pressure processing on the survival of Salmonella Enteritidis and shelf-life of chicken fillets. Food Microbiol. 2018, 70, 55-64. [CrossRef] [PubMed]

221. Chuang, S.; Sheen, S.; Sommers, C.H.; Zhou, S.; Sheen, L.Y. Survival evaluation of Salmonella and Listeria monocytogenes on selective and nonselective media in ground chicken meat subjected to high hydrostatic pressure and carvacrol. J. Food Prot. 2020, 83, 37-44. [CrossRef]

222. Chuang, S.; Sheen, S. High pressure processing of raw meat with essential oils-microbial survival, meat quality, and models: A review. Food Control 2022, 132, 108529. [CrossRef]

223. Yu, H.H.; Chin, Y.-W.; Paik, H.-D. Application of natural preservatives for meat and meat products against food-borne pathogens and spoilage bacteria: A review. Foods 2021, 10, 2418. [CrossRef] [PubMed]

224. Koutchma, T.; Popović, V.; Ros-Polski, V.; Popielarz, A. Effects of ultraviolet light and high-pressure processing on quality and health-related constituents of fresh juice products. Compr. Rev. Food Sci. Food Saf. 2016, 15, 844-867. [CrossRef] [PubMed]

225. Pérez-Lamela, C.; Franco, I.; Falqué, E. Impact of high-pressure processing on antioxidant activity during storage of fruits and fruit products: A review. Molecules 2021, 26, 5265. [CrossRef]

226. Panigrahi, C.; Vishwakarma, S.; Mishra, H.N.; De, S. Kinetic modeling for inactivation of polyphenoloxidase and peroxidase enzymes during ozonation of sugarcane juice. J. Food Process. Preserv. 2021, 45, 1-13. [CrossRef]

227. Zhang, L.; Dai, S.; Brannan, R.G. Effect of high pressure processing, browning treatments, and refrigerated storage on sensory analysis, color, and polyphenol oxidase activity in pawpaw (Asimina triloba L.) pulp. LWT-Food Sci. Technol. 2017, 86, 49-54. [CrossRef]

228. Zhao, G.; Zhang, R.; Zhang, M. Effects of high hydrostatic pressure processing and subsequent storage on phenolic contents and antioxidant activity in fruit and vegetable products. Int. J. Food Sci. Technol. 2017, 52, 3-12. [CrossRef]

229. Sousa, S.G.; Delgadillo, I.; Saraiva, J.A. Effect of thermal pasteurisation and high-pressure processing on immunoglobulin content and lysozyme and lactoperoxidase activity in human colostrum. Food Chem. 2014, 151, 79-85. [CrossRef]

230. Pallarés, N.; Sebastià, A.; Martínez-Lucas, V.; González-Angulo, M.; Barba, F.J.; Berrada, H.; Ferrer, E. High pressure processing impact on alternariol and aflatoxins of grape juice and fruit juice-milk based beverages. Molecules 2021, 26, 3769. [CrossRef]

231. Sethi, S.; Chauhan, O.P.; Anurag, R.K. Effect of high-pressure processing on quality and stability of green mango blended mayonnaise. J. Food Sci. Technol. 2017, 54, 2341-2350. [CrossRef]

232. Nuñez-Mancilla, Y.; Pérez-Won, M.; Uribe, E.; Vega-Gálvez, A.; Di Scala, K. Osmotic dehydration under high hydrostatic pressure: Effects on antioxidant activity, total phenolics compounds, vitamin C and colour of strawberry (Fragaria vesca). LWT Food Sci. Technol. 2013, 52, 151-156. [CrossRef] 
233. Cap, M.; Paredes, P.F.; Fernández, D.; Mozgovoj, M.; Vaudagna, S.R.; Rodriguez, A. Effect of high hydrostatic pressure on Salmonella spp inactivation and meat- quality of frozen chicken breast. LWT Food Sci. Technol. 2020, 118, 108873. [CrossRef]

234. Borges, A.F.; Cózar, A.; Patarata, L.; Gama, L.T.; Alfaia, C.M.; Fernandes, M.J.; Fernandes, M.H.; Pérez, H.V.; Fraqueza, M.J. Effect of high hydrostatic pressure challenge on biogenic amines, microbiota, and sensory profile in traditional poultry- and pork-based semidried fermented sausage. J. Food Sci. 2020, 85, 1256-1264. [CrossRef] [PubMed]

235. Suprabha Raj, A.; Chakraborty, S.; Rao, P.S. Optimizing the thermal assisted high-pressure process parameters for a sugarcane based mixed beverage using response surface methodology. J. Food Process Eng. 2020, 43, e13274. [CrossRef]

236. Stinco, C.M.; Szczepańska, J.; Marszałek, K.; Pinto, C.A.; Inácio, R.S.; Mapelli-Brahm, P.; Barba, F.J.; Lorenzo, J.M.; Saraiva, J.A.; Meléndez-Martínez, A.J. Effect of high-pressure processing on carotenoids profile, colour, microbial and enzymatic stability of cloudy carrot juice. Food Chem. 2019, 299, 125112. [CrossRef]

237. Stratakos, A.C.; Inguglia, E.S.; Linton, M.; Tollerton, J.; Murphy, L.; Corcionivoschi, N.; Koidis, A.; Tiwari, B.K. Effect of high pressure processing on the safety, shelf life and quality of raw milk. Innov. Food Sci. Emerg. Technol. 2019, 52, 325-333. [CrossRef]

238. Tan, S.F.; Chin, N.L.; Tee, T.P.; Chooi, S.K. Physico-chemical changes, microbiological properties, and storage shelf life of cow and goat milk from industrial high-pressure processing. Processes 2020, 8, 697. [CrossRef]

239. Guo, X.; Chen, M.; Li, Y.; Dai, T.; Shuai, X.; Chen, J.; Liu, C. Modification of food macromolecules using dynamic high pressure microfluidization: A review. Trends Food Sci. Technol. 2020, 100, 223-234. [CrossRef]

240. Ozturk, O.K.; Turasan, H. Latest developments in the applications of microfluidization to modify the structure of macromolecules leading to improved physicochemical and functional properties. Crit. Rev. Food Sci. Nutr. 2021, 1-23. [CrossRef]

241. Kumar, A.; Dhiman, A.; Suhag, R.; Sehrawat, R.; Upadhyay, A.; McClements, D.J. Comprehensive review on potential applications of microfluidization in food processing. Food Sci. Biotechnol. 2022, 31, 17-36. [CrossRef]

242. Mert, I.D. The applications of microfluidization in cereals and cereal-based products: An overview. Crit. Rev. Food Sci. Nutr. 2018, 60, 1007-1024. [CrossRef] [PubMed]

243. Li, Y.; Deng, L.; Dai, T.; Li, Y.; Chen, J.; Liu, W.; Liu, W. Microfluidization: A promising food processing technology and its challenges in industrial application. Food Control 2021, 108794. [CrossRef]

244. Charcosset, C. Classical and recent applications of membrane processes in the food industry. Food Eng Rev. 2021, 13, 322-343. [CrossRef]

245. Cassano, A.; Drioli, E. Integrated Membrane Operations: In the Food Production; De Gruyter: Berlin, Germany, 2013. [CrossRef]

246. Guzel-Seydim, Z.B.; Greene, A.K.; Seydim, A.C. Use of ozone in the food industry. LWT Food Sci. Technol. 2004, 37, 453-460. [CrossRef]

247. Huang, H.W.; Lung, H.M.; Yang, B.B.; Wang, C.Y. Responses of microorganisms to high hydrostatic pressure processing. Food Control 2014, 40, 250-259. [CrossRef]

248. HPP: Equipment, Trends and the Science Behind the Technology. Available online: https://www.foodengineeringmag.com/ articles /98497-hpp-equipment-trends-and-the-science-behind-the-technology (accessed on 14 February 2022).

249. Koutchma, T. Advances in ultraviolet light technology for non-thermal processing of liquid foods. Food Bioprocess Technol. 2009, 2, 138-155. [CrossRef] 